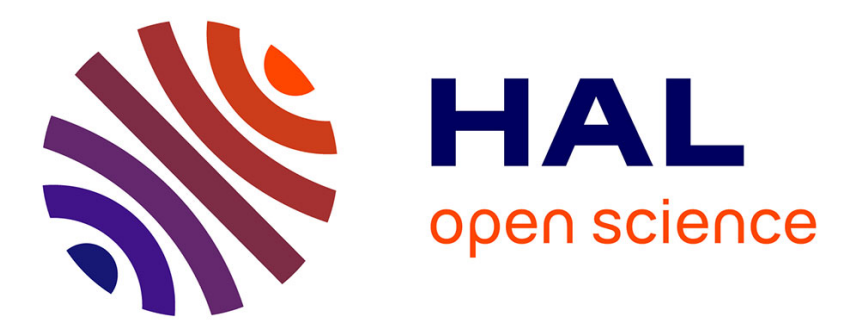

\title{
Crossed prevalence results between subtypes of eating disorder and bipolar disorder: A systematic review of the literature
}

\author{
S. Thiébaut, N. Godart, L. Radon, P. Courtet, S. Guillaume
}

\section{- To cite this version:}

S. Thiébaut, N. Godart, L. Radon, P. Courtet, S. Guillaume. Crossed prevalence results between subtypes of eating disorder and bipolar disorder: A systematic review of the literature. L'Encéphale, 2019, 45 (1), pp.60-73. 10.1016/j.encep.2018.06.001 . hal-02552106

\section{HAL Id: hal-02552106 \\ https://hal.umontpellier.fr/hal-02552106}

Submitted on 21 Oct 2021

HAL is a multi-disciplinary open access archive for the deposit and dissemination of scientific research documents, whether they are published or not. The documents may come from teaching and research institutions in France or abroad, or from public or private research centers.
L'archive ouverte pluridisciplinaire HAL, est destinée au dépôt et à la diffusion de documents scientifiques de niveau recherche, publiés ou non, émanant des établissements d'enseignement et de recherche français ou étrangers, des laboratoires publics ou privés.

\section{(c) (1) $\$$}

Distributed under a Creative Commons Attribution - NonCommerciall 4.0 International 


\section{Crossed prevalence results between subtypes of eating disorder and bipolar disorder: a systematic review of the literature}

Prévalence croisée entre les troubles des conduites alimentaires et les sous-types de troubles bipolaires: Revue systématique de la littérature

\section{S Thiebaut ${ }^{1,2}$, N Godart $^{3,4}$, L Radon ${ }^{3,4}$, Ph Courtet ${ }^{1,2}$, S Guillaume $^{1,2 *}$}

1 : Service d'Urgences et Post Urgences Psychiatriques, CHU Montpellier, Montpellier France

2 : INSERM U1061 et Université de Montpellier, Montpellier France

3 : Département de psychiatrie, Institut Mutualiste Montsouris (IMM), Paris France

4 : CESP, INSERM 1178, Université Paris-Descartes, UVSQ, Villejuif, France

* Corresponding Author: Pr Sébastien Guillaume: Service d'Urgences et Post Urgences Psychiatriques, Hôpital Lapeyronie. Avenue Gaston Giraud, 34295 Montpellier cedex 5, France.

Tel : +33467338581; Fax : +33467338988

E-mail : s-guillaume@chu-montpellier.fr

\section{Conflict of interest}

SG and PC declare having received fees for interventions from Janssen, Otsuka, Lundbeck, BMS and Servier. The authors have declared no conflict of interest in connection with this review.

\section{Authors' contributions}

SG and ST designed and carried out the bibliographical research; ST drafted the article: NG, PC, SG and LR made comments and improved the manuscript; all the authors approved the manuscript. 


\section{Crossed prevalence results between subtypes of eating disorder and bipolar disorder: a systematic review of the literature}

Prévalence croisée entre les troubles des conduites alimentaires et les sous-types de troubles bipolaires : Revue systématique de la littérature

\section{Abstract}

Objective: To assess the association between sub-types of bipolar disorder (BD) (types I and II) and sub-types of eating disorders (EDs) (Anorexia Nervosa, Bulimia Nervosa, Bingeeating disorders) as well as their relative order of occurrence. Methodology: A systematic review of articles estimating prevalence rates for $\mathrm{BD}$ among patients with $\mathrm{ED}$ and vice-versa. We also analysed all articles assessing their relative order of occurrence. Results: Comorbid $\mathrm{BD}$ is common among patients with an ED. From 0.6 to $33.3 \%$ of bipolar subjects have an eating disorder. Conversely, from 0 to $35.8 \%$ of subjects with an ED can present a BD. This co-occurrence has mostly been observed among patients with anorexia of the bulimic/purging type, with bulimia or with binge-eating disorders. The association is less frequent in cases of anorexia of the restrictive type. In contrast, the BD sub-type does not seem to have an impact on the association with EDs. Whilst age at BD onset is earlier in case of a comorbid ED, age at ED onset does not seem to be impacted by the presence of an associated BD. There has been little data on the relative order of occurrence of the two disorders or on the impact of the thymic phase on the expression of EDs. Conclusions: EDs and BD are frequently comorbid, suggesting the need for crossed screening of these pathologies, in particular for EDs with purging behaviours and for patients with early BD onset.

Keywords: bipolar disorder, anorexia nervosa, bulimia nervosa, binge-eating disorders, comorbidity

\section{Résumé}

Objectif: Evaluer l'association entre les sous-types de troubles bipolaires (TB) (type I et II) et les sous types de troubles des conduites alimentaires (TCA) (anorexie, boulimie, hyperphagie boulimique) ainsi que leur chronologie relative d'apparition. Méthodologie: Revue systématique des articles ayant estimé une prévalence du TB chez des patients souffrant de TCA et réciproquement. Nous avons également analysé tous les articles évaluant leur chronologie relative d'apparition. Résultats: Un trouble bipolaire comorbide est fréquent chez les sujets souffrant de TCA. Entre 0.6 et $33.3 \%$ de sujets bipolaires présenteraient un TCA. Réciproquement, entre 0 et $35.8 \%$ de sujets avec un TCA pourraient présenter un TB. Cette cooccurrence est le plus souvent observée chez les sujets présentant: une anorexie de type crises de 
boulimie/vomissements ou prise de purgatifs, une boulimie ou une hyperphagie boulimique. Cette association est moins fréquente en cas d'anorexie de type restrictif. A l'inverse, le sous-type de TB semble ne pas avoir d'impact sur l'association avec un TCA. Alors que l'âge de début du TB est plus précoce en cas de TCA comorbide, l'âge de début du TCA ne semble pas être impacté par l'existence d'un trouble bipolaire associé. Il existe peu de données sur les chronologies d'apparition relatives des deux troubles et l'impact des phases thymiques sur l'expression du TCA. Conclusions: TCA et TB sont fréquemment comorbides, ce qui impose un dépistage croisé de ces pathologies, en particulier pour les TCA avec des manifestations purgatives et chez les patients avec un TB à début précoce.

Mots clés: trouble bipolaire, anorexie mentale, boulimie, hyperphagie boulimique, comorbidité

\section{Introduction}

Bipolar disorders (BD), like eating disorders (ED), are frequent psychiatric conditions occurring in young adults. The lifetime risk of developing BD is $1.32 \%(1.29-1.36)$ for men and 1.84 (1.80-1.88) for women [1], whilst the risk of developing an ED is 3.00\% (2.95-3.06) for women and $0.17 \%(0.16-0.19)$ for men [1]. Since the nineties, a few literature reviews have raised the issue of a frequent comorbidity between these disorders [2] and have reported that from $5.3 \%$ to $31 \%$ of patients with BD present an ED; conversely, about $8 \%$ of patients presenting an ED develop a BD in the course of their lives [3-6].

There are however many limitations to these reviews. The first limitation results from the heterogeneity of the clinical forms of ED and BD under consideration. Previous studies have thus focused on BD as a whole, without making a distinction between type I BD and type II BD. Given the differences between these BD sub-types, particularly clinical and biological differences, [7,8], it is possible that their respective associations with EDs differ. Similarly, although the most commonly defined ED types - Anorexia Nervosa (AN), Bulimia Nervosa (BN) and Binge-eating disorders (BED) - show differences in frequency of association with $\mathrm{BD}$, they have not always been differentiated in studies. The second limitation is the absence of any synthesis of the published data concerning the relative order of occurrence of these disorders. The interpretation of the data on lifetime prevalence is restricted if the chronological link between these disorders is not known. A third limitation concerns the methodological disparities across studies, in particular the variability in the symptom profiles under study and the diagnostic criteria used to define the disorders [9]. The diagnostic classifications used have thus followed the evolution of the different DSM editions, with the use of the Research Diagnostic Criteria (RDC) for the earliest studies. With time, criteria have become less restrictive, thus leading to an increase in reported prevalence. For instance, the early classifications reported a maximum of $8.5 \% \mathrm{BD}$ in the general population, whereas the most recent report up to $33.3 \%$. Furthermore, most studies were cross-sectional; it is therefore not possible to establish a chronological sequence of events, which could increase the risk of making incorrect diagnoses in pathologies where the diagnosis is unstable over time. Indeed, depending on the age of the subjects under study, certain BD or ED sub-types with a late onset, such as BED, may not yet have developed. The diagnostic tools used are also very heterogeneous, ranging from simple self-report questionnaires to structured standardised interviews. Finally, these reviews were generally carried out by teams 
specialised in one of the disorders, and who consequently lacked knowledge in the other pathology. It therefore seemed necessary to carry out a literature review that addressed these limitations.

The objectives of this systematic review were first to study the respective prevalence of ED and comorbid BD, differentiating their sub-types, and secondly, to study their development through their relative order of occurrence. Methodological differences in the various studies were taken into consideration in order to interpret the relationships between these disorders.

\section{Method}

This systematic review followed the PRISMA recommendations (Preferred Reporting Items for Systematic Reviews and Meta-Analysis) [10].

A systematic review on Pubmed was carried out on articles published between 1980 and May $31^{\text {st }}$ 2017. Inclusion criteria were the following: studies published in English, French or Spanish, including patients with EDs and patients with BD, enabling a calculation of the prevalence of these comorbidities. Studies that did not enable the calculation of the prevalence were excluded (figure 1). The method and the article selection procedure are available in the Supplementary Material section.

\section{Results}

Seventy-nine studies on the prevalence and co-occurrence of ED/BD were retained. Some had been carried out on clinical populations (hospitalised or ambulatory) with EDs or BD and others on the general population. The studies were divided into 3 categories: general population (6 studies), patient populations with BD (34 studies) and patient populations with EDs (39 studies).

\section{Study on the comorbidity of bipolar disorders/eating disorders in the general population:}

Six studies [11-16] in the general population focused on BD/ED comorbidity. Table 1 gives a summary of these studies: the $\mathrm{BD}$ and $\mathrm{ED}$ prevalence figures observed were proportionally higher when the definitions of these disorders were less strict (some studies, such as Angst et al. [12], considered sub-clinical forms, where BED was defined by the presence of more than 4 episodes a year). Logically, the prevalence of ED and BD also increases with the average age of the samples. Only two studies $[11,15]$ were carried out on an adult population, the others concerned adolescents or young adults (19-20-year-olds); these two studies found the lowest frequencies of the disorders, using subsyndromal definitions. The prevalence also increased with the number of ED sub-types under study. Frequency was very low if only AN was considered [11], but higher if both $\mathrm{AN}$ and $\mathrm{BN}$ were considered together [14]. The larger the sample, the greater was the number of cases observed for each disorder. Therefore, the greater the number of cases observed, the greater the probability of observing comorbid cases, which contributes to explaining apparently contradictory results. For instance, in the Fogarty et al. study [11], the fact that only AN was taken into account - a 
rare disorder in that sample $(0.1 \%)$ - could explain the absence of any link between BD and ED.

Three studies found a significantly increased frequency of BD among patients with an ED compared to the general population. Among adolescents, Lewinsohn et al [14] reported that the risk of bipolar disorders not-otherwise-specified (BD-NOS) was 4.8 times greater than in case of eating disorders not-otherwise-specified (EDNOS). Swanson [16] estimated this risk to be 7.3 times greater for BN and 3 times greater for BED. Finally, among adults, Hudson et al. estimated the risk of BD to be 4.7 times greater for BN, 3.6 times for BED and 3.5 times for any ED subtypes with purging behaviours.

The main limitation of these studies is that the prevalence results were not adjusted on possible confounding factors (psychiatric or addictive comorbidities, history of early abuse, etc.). Another major limitation is the cross-sectional nature of most of these studies. In this sense, Lewinshon's longitudinal study [13] is particularly informative because it involved a prospective follow-up of adolescents up to 24 years of age, thus limiting the risk of underestimating the link (because of late onset age and the possible diagnostic instability).

To sum up, the study of comorbidity between EDs (particularly AN) and BD in the general population is difficult because of the low frequency of these two types of disorders. There are however arguments in favour of an increased frequency of BD in patients with BN or BED. Two studies carried out on large samples of adults [15] or adolescents [14] showed that the risk of presenting type I or type II BD was significantly greater in case of BN (alone or associated with AN) or BED, compared to the general population. AN or BED-NOS, on their own, do not increase this risk.

Compared to the general population, adolescent patients presenting BD-NOS have an increased risk of having an ED (AN or $\mathrm{BN})$ [16]. Adults presenting hypomania seem to more frequently present BED (4 episodes a year) [12].

\section{Studies on the lifetime prevalence of EDs among patients with BD.}

Table 2 gives a summary of the thirty-four studies [8,17-49] assessing the prevalence of EDs in patient populations presenting BD.

The prevalence of $\mathrm{AN}, \mathrm{BN}$ and $\mathrm{BED}$ in the general population is about $0.9 \%, 1-2.3 \%$ and $1.9-3.5 \%$ respectively [50]. Figure 2 gives a summary of BD prevalence rates overall (Figure 2a), followed by prevalence rates per sub-type (BD I and BD II) differentiating the different EDs (Figures $2 \mathrm{~b}$ and $2 \mathrm{c}$ ). Figure 1a clearly suggests that in a population with BD, these prevalence figures are higher, with up to $8.6 \%$ for $\mathrm{AN}, 24.6 \%$ for $\mathrm{BN}$ and $28.8 \%$ for $\mathrm{BED}$ according to studies. This comorbidity seems to be more frequent in disorders presenting bingeing episodes: BN and BED.

Results are very heterogeneous across studies: AN prevalence varies from 0 to $8.6 \%, \mathrm{BN}$ prevalence from 2.3 to $24.6 \%$ and BED prevalence from 0 to $28.8 \%$. The range of the different values found for AN is thus smaller than for BED.

In type I BD, a prevalence of EDs from 2.3 to $35.2 \%$ was found, from 0 to $8.6 \%$ for $\mathrm{AN}$, from 2.3 to $24.6 \%$ for $\mathrm{BN}$ and from 8.9 to 17.6 for $\mathrm{BH}$. Figure $2 \mathrm{~b}$ suggests that, across studies, the prevalence of BED is higher than for AN. As for BN, the inter-study variability is 
substantial. However, the prevalence of AN in patients suffering from type I BD seems lower than the prevalence of $\mathrm{BN}$ and $\mathrm{BED}$ across all studies considering the three types of ED. A $\mathrm{BN} / \mathrm{BED}$ comparison was not possible given the diversity of the results.

In type II BD, the prevalence of EDs ranged from 5.6 to $40 \%$ : 0.5 to $4.2 \%$ for AN, 5.4 to $15.8 \%$ for $\mathrm{BN}$ and 5.6 to $13.7 \%$ for BED. The prevalence of $\mathrm{AN}$ among patients presenting type II BD is systematically lower than the prevalence figures for $\mathrm{BN}$ and $\mathrm{BED}$ (figure $2 \mathrm{c}$ ). A $\mathrm{BN} / \mathrm{BED}$ comparison was not possible given the diversity of the results.

Patient age does not seem to be a contributory factor to explaining the variations observed, as most studies focused on populations between 30 and 45 years of age. In the study by Martin et al. [49], the average age of 16 could explain the absence of BED, for which onset occurs much later [15].

For women, Zerwas et al. [51] found a peak of occurrence at 15 years of age for AN, and 22 for $\mathrm{BN}$.

It is interesting to see that the highest ED prevalence figures - up to $33.3 \%$ - have all been based on recent classifications, whereas earlier classifications (up to the DSM-III-R) only yielded $8.5 \%$ ED. The early studies only took one ED (BN) or two EDs (AN and BN) into account, and quite often did not consider BED, which appeared later in the DSM IV classification. The use of the DSM 5 criteria increased the frequency of the different ED subtypes at the expense of EDNOS (deletion of the amenorrhea criterion, decrease in the numbers of bingeing episodes for BN and BED episodes [52]). With time, classifications have become less restrictive and have led to an increase in the reported prevalence of EDs.

Studies that excluded patients presenting substance abuse, psychosis or suicidal behaviour, or even personality disorders $[18,23,27,29,33,37,44]$ found a lower prevalence of EDs, ranging from 6.6 to $15.2 \%$. These studies probably underestimated the prevalence of the association, due to frequent comorbidities between the different diagnoses.

The study populations comprised 43 to $100 \%$ women. However, EDs occur more frequently in women than in men. Therefore, for the same number of sub-types considered, and with similar diagnostic criteria, the frequency is greater if the percentage of women is high. The study by Azorin et al. [40] is in this respect interesting, because it makes a distinction between prevalence figures for men and women.

No differences in prevalence were found in relation to whether the patients recruited were ambulatory or hospitalised.

To sum up, if we analyse the studies that have focused on AN, BN and BED at the same time, the frequency of EDs among patients presenting BD varies from one study to another from 9.9 to $28.8 \%$. According to these same studies, it ranges from 14.4 to $24.7 \%$ for type I $\mathrm{BD}$ and from 13.7 to $30 \%$ for type II BD.

Only one study [49] included a control group and found a greater prevalence of bulimic episodes induced by stress and emotion-related eating behaviours in young people with bipolar disorder $(\mathrm{p}=0.001)$. 
The eating disorder for which the prevalence is the lowest in patients presenting type I or type II BD is AN. BED -8.3 to $28.8 \%$ - and Bulimia - 2.3 to $24.6 \%$ - are more frequent.

The studies that make a distinction between type I BD and type II BD do not allow a conclusion to be drawn on the prevalence of EDs according to BD sub-type, as no statistical test was carried out to make these comparisons. Some studies $[8,26,30,44,47]$ found prevalence figures for EDs that are higher in type II BD compared to type I BD. However, other studies $[20,33,37]$ found the opposite trend, with more EDs in type I BD compared to type II BD.

Studies on the lifetime prevalence of BD among patients with an ED.

Table 3 gives a summary of the thirty-nine studies [53-91] that assessed the prevalence of $\mathrm{BD}$ in patient populations with an ED.

20 studies included control groups and 5 studies [77, 86, 88-90] found a significantly greater frequency of BD among patients with an ED compared to the control groups. Because these studies were carried out on the largest samples, Tseng et al. [89] were able to evidence significant differences in the comparisons of groups of AN, BN, BED and EDNOS subjects with control groups $(\mathrm{p}<0.0001)$. Among patients with AN, ten years after hospitalisation, a greater frequency of BD-NOS was found compared to a control group $(\mathrm{p}<0.01)$ [77]. Godart et al. [88] also found a significantly greater frequency of $\mathrm{BD}$ in the purely restrictive AN (AN-r) group compared to control subjects.

Figure 3 summarises the prevalence rates for $\mathrm{BD}$ and its sub-types. The prevalence of $\mathrm{BD}$ is about $1 \%$ in the general population ( $0.6 \%$ for type I BD and $0.4 \%$ for type II BD) and $2.4 \%$ across the bipolar spectrum [92]. In an ED population, whatever the ED sub-type, the prevalence appears much higher, with up to $26.1 \%$ for type I BD and $26.7 \%$ for type II BD.

In the overall population presenting EDs, the prevalence of type I BD ranges from 0 to $26.1 \%$, type II BD from 0 to $19.8 \%$ and BD-NOS from 0 to $9.7 \%$. It is worth noting that the 9 studies $[54,55,60,64,68,71,80,85,91]$ that did not find any type II BD were carried out on 50 or fewer subjects for six of them (and 78, 98 and 171 subjects for the other three studies $[60,64,91])$. The 8 studies $[53,54,56,68,80,84,85,91]$ that did not find any type II BD were carried out on 50 patients or fewer for 5 of them (with 51, 90 and 98 patients for the other three $[53,84,91])$, which suggests a probable lack of statistical power.

In $\mathbf{A N}$, the prevalence figures found were the following: from 0 to $12.6 \%$ for type I BD, from 0 to $5.6 \%$ for type II BD and from 0 to $9.7 \%$ for BD-NOS. It seems that in a population with AN, type I BD is the most common, compared to type II BD and BD-NOS. Studies focusing on the prevalence of several ED sub-categories and differentiating purely restrictive anorexia from binging-purging anorexia are rare, but they all found the same results: a apparently higher prevalence of $\mathrm{BD}$ in the $\mathrm{AN}-\mathrm{BN}$ sub-group compared to the restrictive subgroup $[57,58,60,61,69,88]$, although no significant difference was found, probably due to a lack of statistical power.

In the AN-r category, the prevalence figures found were the following: from 0 to $6.3 \%$ for type I BD, 0 to $1.8 \%$ for type II BD and $0 \%$ (only one study) for BD-NOS. In the AN-BN category, the prevalence figures were: 0 to $25.5 \%$ for type I BD, 1 to $5.6 \%$ for type II BD and 0 to $3.3 \%$ for BD-NOS. 
In the BN category, the prevalence figures found were the following: from 0 to $20 \%$ for type I BD, 0 to $21.6 \%$ for type II BD, and 0 to $9 \%$ for BD-NOS. The prevalence values for type I and type II BD among patients presenting BN are fairly similar. As for BD-NOS, the prevalence was not as high as for type I and type II BD and was fairly close to that found in AN.

In the BED category, only 10 studies gave prevalence figures, making it difficult to draw any conclusions. The prevalence figures range from 0 to $22.7 \%$ for type I BD and 0 to $26.7 \%$ for type II BD.

Samples of patients presenting an ED mainly concern women; no study was specifically focused on men.

Studies that only focused on hospitalised patients found a prevalence of BD ranging from 2.5 to $8.3 \%$. Studies focusing on both hospitalised and ambulatory patients did not make the distinction in the analyses.

Classifications have evolved. The prevalence figures found in the recent studies are higher. If we consider all studies up to the DSM-IIIR, we find prevalence figures for BD ranging from 0 to $18.5 \%$, versus prevalence figures ranging from 0 to $35.8 \%$ for post-DSMIV studies.

Certain studies presented more restrictive exclusion criteria, such as substance abuse, patients with unstable $\mathrm{BD}$, suicide risk or serious psychosomatic disorder $[55,62,63,76,85$, 87-89, 93]. The prevalence figures found for these studies were mostly in the lower bracket of the prevalence figures observed.

In summary, EDs with purging/compulsive behaviours are the disorders the most commonly associated with $\mathrm{BD}$. BN is the most frequently associated disorder with BD. If we exclude studies with small samples, the prevalence varies from $0.8 \%$ to $36 \%$. For BED, there are fewer studies. Excluding small sample studies, the prevalence of BD ranges from $0.4 \%$ to 49.3\%. Concerning AN as a whole, the prevalence of BD, excluding small sample studies, is 0 to $16.7 \%$. For the AN-BN subtype, we find prevalence figures for BD from 0 to $29.1 \%$. The purely restrictive AN subtype shows prevalence figures ranging from 0 to $8.1 \%$, which is much lower than for the AN type involving episodes of bulimia. There is no data enabling a comparison between the frequency of occurrence of $\mathrm{BD}$ for $\mathrm{AN}, \mathrm{BN}$ and $\mathrm{BED}$, or their subtypes.

\section{Relative order of occurrence of ED/BD}

Table 4 gives a list of the relevant studies. In a population presenting EDs with a mean age of 21 years, Godart et al. [88] found onset of BD occurring around the same time as or later than ED onset. Conversely, other studies [28, 33] found BD onset occurring before the ED onset among patients with a mean age of 40-41 years. This preliminary data does not enable any conclusions to be drawn, given the small size of the samples.

Concerning the impact of comorbidity on age at BD onset: five studies on almost 3000 subjects presenting BD found similar results for significantly earlier age at BD onset in the case of a comorbid ED [33, 34, 47, 48, 94]. McElroy et al. [47] also found an age at BD onset 
significantly earlier in case of a comorbid ED ( $\mathrm{p}=0.02)$. However, when stratification was performed on ED sub-categories, the results were no longer significant, probably because of a lack of statistical power $(\mathrm{p}=0.06)$. This early onset could be aggravated by the presence of substance abuse. Becker et al. [95] have thus reported that in a population of 347 patients presenting $\mathrm{BH}$, the presence of substance abuse comorbid with the mood disorder was associated with an earlier age at BH and BD onsets.

To sum up, age at BD onset is earlier in patients with a comorbid ED and even earlier in case of AN. Subjects with BD before or around puberty are more likely to have a comorbid ED. Age at ED onset does not seem to be affected by a comorbid BD.

\section{Discussion}

In this systematic review of the literature, whatever the methodological approach (general population, bipolar population, or ED population), the lifetime comorbidity of $\mathrm{ED} / \mathrm{BD}$ is frequent.

Studies involving general populations found a significantly increased frequency of BD among patients presenting EDs compared to the general population, whether for adolescents or adults. This frequency is 4.7 to 7.3 times greater for $\mathrm{BN}, 3$ to 3.6 times greater for $\mathrm{BH}$ and 3.5 times greater for any ED with purging.

In clinical populations, if we consider the studies covering $80 \%$ of the largest samples, we find an ED prevalence among patients with BD ranging from $0.6 \%$ to $33.2 \%$, and a prevalence of $\mathrm{BD}$ in patients with EDs ranging from 0 to $26.1 \%$ for type I and 0 to $19.8 \%$ for type II BD.

The EDs for which this co-occurrence is the most frequent, are: AN-BN, BN and BED. BD comorbidity is less present in case of purely restrictive AN, whether for type I or type II BD. The presence of purging behaviours therefore seems to be a risk factor with respect to this lifetime comorbidity. The recent study by Godart et al. [88] differentiating purging forms ( $\mathrm{BN} \mathrm{P}+$ ) and non-purging forms ( $\mathrm{BN} \mathrm{P-)}$ of $\mathrm{BN}$ found $\mathrm{BD}$ prevalence rates of $25.6 \%$ and $10.5 \%$ respectively. We could therefore hypothesise that the presence of purging behaviours is even more closely associated with BD than the presence of bulimic episodes. Conversely, BD sub-types do not seem to have an impact on the association with EDs.

Regarding the onset of disorders, in clinical populations of patients presenting BD, female patients with a comorbid ED had earlier BD onset; patients with a form of BD occurring before or around puberty are more likely to have a comorbid ED. The data is still too limited to draw any conclusion on the respective order of occurrence of the two disorders.

The marked comorbidity between $\mathrm{BD}$ and EDs requires systematic screening for the other disorder in each of these pathologies. A number of simple screening tools available in the French language can be used. The Mood Disorders Questionnaire (MDQ) has proved efficacious in screening for bipolar disorders among patients presenting EDs [64]. Similarly, a simple screening tool used for EDs such as the SCOFF questionnaire [96] could be of use. Screening should be all the more systematic when dealing with sub-populations that are at risk (purging EDs, early-onset bipolar disorders). 
The joint treatment of these disorders is needed, since an eating disorder can lead to the deterioration of BD: poorer daily functioning between mood episodes, more serious anxiety disorders, more frequent thymic episodes, particularly depressive episodes [34][97]. The impact of BD on ED characteristics is more difficult to assess in the light of the current literature. The existence of an ED comorbid with BD could increase suicide risk $(47.4 \%$ among BD patients with a lifetime ED versus $27.8 \%$ among BD patients without an ED, $\mathrm{p}<0.01)$, particularly in type I patients $(61.8 \%$ versus $35.7 \%$ in type II patients) [8]. Finally, this comorbidity increases mortality, as was shown by a recent study [70] on patients with AN where the standardised mortality ratio (SMR) was $3.2(95 \% \mathrm{IC}=2.7-3.9)$ in the absence of a psychiatric comorbidity, 8.2 (95\% IC=7.3-9.2) in case of a psychiatric comorbidity and 8.5 (95\% IC $=5-13.4)$ in case of comorbid BD. In particular, women with $\mathrm{AN}$ and comorbid $\mathrm{BD}$ had mortality rates from non-natural causes 40 times higher than women in the general population. This comorbidity should guide prescriptions in $\mathrm{BD}$, as anti-psychotic drugs have negative consequences on eating behaviours, especially increased food craving and loss of dietary control [98].

The dynamics and the order of occurrence of these two disorders remain understudied. There are probably crossed vulnerability factors that trigger the emergence of both disorders. Studies on families have thus shown that among parental psychiatric disorders, BD is the most frequently associated disorder with an increased risk of ED in children [99].

Although the data consistently suggests that the existence of an ED in case of BD is associated with early-onset BD, it is currently insufficient regarding the impact of this comorbidity on age at ED onset. Similarly, it is not currently possible to determine whether certain forms of ED chronologically precede and trigger the emergence of $\mathrm{BD}$, or vice-versa. A number of methodological difficulties could explain this issue. Firstly, the mean age of ED onset varies from one form to another: anorexia, in the general population, has an earlier age at onset than BD, and BED an older age at onset than BD. Secondly, BD, whatever the thymic phase, is associated with frequent changes in eating behaviour: anorexia, hypophagia, weight loss, hyperphagia, and increase in appetite all interfere with ED diagnosis. Ramaccioti et al [28] found 4 patients for whom an ED had started during a manic episode, 7 during depressive episodes and 1 during a euthymic episode. Mantere et al. [100 ] found an association between EDs and depression $(\mathrm{r}=0.150 .32, \mathrm{p}<0.05)$. Seixas et al. [36] and Torrent et al. [101] found more frequent EDs in depressive episodes. Similarly, people presenting EDs often present thymic symptoms interfering with the diagnosis of a thymic disorder. People with BED thus often describe depressive and anxious symptoms before a binging episode, followed by relief during the episode, later followed by depressive affects, selfdepreciation and guilt after the episode has ended. Similarly, among people with AN, elation, slowing down, irritability, mood changes, hyperactivity, logorrhoea, and sleep disorders have all been observed, and are possibly linked to undernourishment. These different crossed symptoms make it difficult to study BD/ED chronologies.

Future studies should differentiate ED sub-types to confirm the risk-prone populations we have evidenced. Particular attention should be given to the order of occurrence of the two disorders so as to understand it more fully. Indeed, respective age at onset for the two disorders is of great clinical and prognostic interest, and unfortunately there is still a lack of studies on the subject.

Beyond the objectives of this review, the association between BD and EDs raises the issue of the link between AN and BD. McElroy et al. [3], as well as Godart et al (not yet published), suggest two reasons for this comorbidity: (1) ED and BD are two distinct entities, or they 
share aetiological mechanisms that constitute risk factors one for the other; (2) there could be vulnerability factors that are common to both disorders. Data from a variety of sources currently supports this hypothesis. A bipolar disorder could thus be the parental psychiatric pathology that most increases the risk of the children developing an eating disorder [99]. BD and EDs share certain common clinical characteristics, such as emotional dysregulation, high suicide risk or common neuropsychological deficits, such as those affecting decision-making processes [102, 103]. Finally, there are pre-morbid personality traits, such as impulsiveness and emotional dysregulation which are frequently found in bipolar disorder or certain eating disorders (especially BN and BED) [3]. This data overall suggests that there is a vulnerability common to the two disorders, and that further investigation is required.

In $\mathrm{AN}$, there is a high frequency of early major depressive episode. This occurrence should alert clinicians to the risk of developing BD. Indeed, as pointed out by Akiskal [32], the occurrence of depression before the age of 20 signals an increased risk of developing BD thereafter. $25 \%$ of children or adolescents presenting a major depressive episode thus develop $\mathrm{BD}$ in the 2 to 5 years following [32].

There are many advantages to our review (systematic review, inclusion of studies on clinical and general populations, etc.); there are nevertheless limitations. The use of different definitions and concepts for BD and ED diagnoses, and the changes in these definitions have made it difficult to compare studies. Successive changes in ED and BD diagnostic criteria have undeniably impacted patient selection and the prevalence figures found. Furthermore, there were weaknesses in the methodology of some studies, for instance, the size of the samples or the inclusion criteria (inclusion of women only, exclusion of patients with addictive comorbidities, etc.). As for studies on clinical populations, the recruiting establishments also could have impacted the prevalence results. In line with the results reported by Hudson et al. [53], the prevalence of BD among hospitalised patients was much higher than for ambulatory patients; as Godart et al. [6] remarked, patients who are treated are not representative of all the patients with EDs, as a result of a filtering effect in access to care. Furthermore, patients with multiple diagnoses are more likely to see a doctor and ask to be treated, and this trend is commonly known as Berkson's paradox.

To conclude, this review suggests a non-negligible comorbidity between BD and EDs of the purging type, leading to very serious consequences for patients. A screening for EDs is therefore paramount in case of $\mathrm{BD}$, particularly in early onset, and vice-versa a screening for $\mathrm{BD}$ in presence of an ED. Because the association is even more marked, the screening for $\mathrm{BD}$ should be particularly careful in cases of the ED with purging/compulsive behaviour. 


\section{Conflicts of interest:}

SG and PC have received payment for various interventions with Jansse, Otsukan Lundbeck, BMS and Servier. The other authors do not have any conflicts of interest to declare in connection with this review.

\section{Authors' contributions:}

SG and ST designed the review and carried out the bibliographical search. ST wrote the article; NG, PC, SG, LR provided comments and improved the manuscript; all the authors approved the manuscript.

\section{Bibliographie}

[1] Pedersen CB, Mors O, Bertelsen A, Waltoft BL, Agerbo E, McGrath JJ, et al. A comprehensive nationwide study of the incidence rate and lifetime risk for treated mental disorders. JAMA Psychiatry 2014;71:573-81.

[2] Mury M, Verdoux H, Bourgeois M. [Comorbidity of bipolar and eating disorders. Epidemiologic and therapeutic aspects]. L'Encéphale 1995;21:545-53.

[3] McElroy SL, Kotwal R, Keck Jr. PE, Akiskal HS. Comorbidity of bipolar and eating disorders: distinct or related disorders with shared dysregulations? J Affect Disord 2005;86:107-27.

[4] McElroy SL, Kotwal R, Keck PE. Comorbidity of eating disorders with bipolar disorder and treatment implications. Bipolar Disord 2006;8:686-95.

[5] Álvarez Ruiz EM, Gutiérrez-Rojas L. Comorbilidad entre el trastorno bipolar y los trastornos de la conducta alimentaria. Rev Psiquiatr Salud Ment 2015;8:232-41.

[6] Godart NT, PERDEREAU F, JEAMMET P, FLAMENT M-F. Comorbidité des troubles alimentaires et des troubles de l'humeur. /data/revues/00137006/00310005/575/ 2008.

[7] Caseras X, Lawrence NS, Murphy K, Wise RG, Phillips ML. Ventral striatum activity in response to reward: differences between bipolar I and II disorders. Am J Psychiatry 2013;170:533-41.

[8] Goffin KC, Dell'Osso B, Miller S, Wang PW, Holtzman JN, Hooshmand F, et al. Different characteristics associated with suicide attempts among bipolar I versus bipolar II disorder patients. J Psychiatr Res 2016;76:94-100.

[9] Godart, Perdereau F, Rein Z, Berthoz S, Wallier J, Jeammet P, et al. Comorbidity studies of eating disorders and mood disorders. Critical review of the literature. J Affect Disord 2007;97:37-49.

[10] Moher D, Liberati A, Tetzlaff J, Altman DG, PRISMA Group. Preferred reporting items for systematic reviews and meta-analyses: the PRISMA statement. PLoS Med 2009;6:e1000097.

[11] Fogarty F, Russell J m., Newman S c., Bland R c. Mania. Acta Psychiatr Scand 
1994;89:16-23.

[12] Angst J. The emerging epidemiology of hypomania and bipolar II disorder. J Affect Disord 1998;50:143-51.

[13] Lewinsohn PM, Striegel-Moore RH, Seeley JR. Epidemiology and natural course of eating disorders in young women from adolescence to young adulthood. J Am Acad Child Adolesc Psychiatry 2000;39:1284-92.

[14] Lewinsohn PM, Shankman SA, Gau JM, Klein DN. The prevalence and co-morbidity of subthreshold psychiatric conditions. Psychol Med 2004;34:613-22.

[15] Hudson JI, Hiripi E, Pope HG, Kessler RC. The Prevalence and Correlates of Eating Disorders in the National Comorbidity Survey Replication. Biol Psychiatry 2007;61:348-58.

[16] Swanson, Crow SJ, Le Grange D, Swendsen J, Merikangas KR. Prevalence and correlates of eating disorders in adolescents: Results from the national comorbidity survey replication adolescent supplement. Arch Gen Psychiatry 2011;68:714-23.

[17] Strakowski SM, Tohen M, Stoll AL, Faedda GL, Goodwin DC. Comorbidity in mania at first hospitalization. Am J Psychiatry 1992;149:554-6.

[18] Strakowski SM, Tohen M, Stoll AL, Faedda GL, Mayer PV, Kolbrener ML, et al. Comorbidity in psychosis at first hospitalization. Am J Psychiatry 1993;150:752-7.

[19] McElroy, Strakowski SM, Keck PE, Tugrul KL, West SA, Lonczak HS. Differences and similarities in mixed and pure mania. Compr Psychiatry 1995;36:187-94.

[20] Krüger S, Shugar G, Cooke RG. Comorbidity of binge eating disorder and the partial binge eating syndrome with bipolar disorder. Int J Eat Disord 1996;19:45-52.

[21] Schuckit MA, Tipp JE, Anthenelli RM, Bucholz KK, Hesselbrock VM, Nurnberger JI. Anorexia nervosa and bulimia nervosa in alcohol-dependent men and women and their relatives. Am J Psychiatry 1996;153:74-82.

[22] Edmonds LK, Mosley BJ, Admiraal AJ, Olds RJ, Romans SE, Silverstone T, et al. Familial bipolar disorder: preliminary results from the Otago Familial Bipolar Genetic Study. Aust N Z J Psychiatry 1998;32:823-9.

[23] Cassano GB, Pini S, Saettoni M, Rucci P, Dell'Osso L. Occurrence and clinical correlates of psychiatric comorbidity in patients with psychotic disorders. J Clin Psychiatry 1998;59:60-8.

[24] Pini S, Dell'Osso L, Mastrocinque C, Marcacci G, Papasogli A, Vignoli S, et al. Axis I comorbidity in bipolar disorder with psychotic features. Br J Psychiatry J Ment Sci 1999;175:467-71.

[25] Vieta E, Colom F, Corbella B, Martínez-Arán A, Reinares M, Benabarre A, et al. Clinical correlates of psychiatric comorbidity in bipolar I patients. Bipolar Disord 2001;3:253-8.

[26] McElroy, Altshuler LL, Suppes T, Keck PE, Frye MA, Denicoff KD, et al. Axis I psychiatric comorbidity and its relationship to historical illness variables in 288 patients with bipolar disorder. Am J Psychiatry 2001;158:420-6.

[27] MacQueen GM, Marriott M, Begin H, Robb J, Joffe RT, Young LT. Subsyndromal symptoms assessed in longitudinal, prospective follow-up of a cohort of patients with bipolar disorder. Bipolar Disord 2003;5:349-55.

[28] Ramacciotti CE, Paoli RA, Marcacci G, Piccinni A, Burgalassi A, Dell'Osso L, et al. 
Relationship between bipolar illness and binge-eating disorders. Psychiatry Res 2005;135:165-70.

[29] Alciati A, D’Ambrosio A, Foschi D, Corsi F, Mellado C, Angst J. Bipolar spectrum disorders in severely obese patients seeking surgical treatment. J Affect Disord 2007;101:131-8.

[30] Wildes JE, Marcus MD, Fagiolini A. Eating disorders and illness burden in patients with bipolar spectrum disorders. Compr Psychiatry 2007;48:516-21.

[31] Wildes JE, Marcus MD, Fagiolini A. Prevalence and correlates of eating disorder comorbidity in patients with bipolar disorder. Psychiatry Res 2008;161:51-8.

[32] Lunde AV, Fasmer OB, Akiskal KK, Akiskal HS, Oedegaard KJ. The relationship of bulimia and anorexia nervosa with bipolar disorder and its temperamental foundations. $\mathrm{J}$ Affect Disord 2009;115:309-14.

[33] McElroy, Frye MA, Hellemann G, Altshuler L, Leverich GS, Suppes T, et al. Prevalence and correlates of eating disorders in 875 patients with bipolar disorder. J Affect Disord 2011;128:191-8.

[34] Brietzke E, Moreira CLR, Toniolo RA, Lafer B. Clinical correlates of eating disorder comorbidity in women with bipolar disorder type I. J Affect Disord 2011;130:162-5.

[35] Schoofs N, Chen F, Bräunig P, Stamm T, Krüger S. Binge eating disorder and menstrual cycle in unmedicated women with bipolar disorder. J Affect Disord 2011;129:75-8.

[36] Seixas C, Miranda-Scippa A, Nery-Fernandes F, Andrade-Nascimento M, Quarantini LC, Kapczinski F, et al. Prevalence and clinical impact of eating disorders in bipolar patients. Rev Bras Psiquiatr São Paulo Braz 1999 2012;34:66-70.

[37] McElroy, Crow S, Biernacka JM, Winham S, Geske J, Cuellar Barboza AB, et al. Clinical phenotype of bipolar disorder with comorbid binge eating disorder. J Affect Disord 2013;150:981-6.

[38] Jen A, Saunders EF, Ornstein RM, Kamali M, McInnis MG. Impulsivity, anxiety, and alcohol misuse in bipolar disorder comorbid with eating disorders. Int J Bipolar Disord 2013;1:13.

[39] Gao K, Wang Z, Chen J, Kemp DE, Chan PK, Conroy CM, et al. Should an assessment of Axis I comorbidity be included in the initial diagnostic assessment of mood disorders? Role of QIDS-16-SR total score in predicting number of Axis I comorbidity. J Affect Disord 2013;148:256-64.

[40] Azorin J-M, Belzeaux R, Kaladjian A, Adida M, Hantouche E, Lancrenon S, et al. Risks associated with gender differences in bipolar I disorder. J Affect Disord 2013;151:1033-40.

[41] Perugi G, Medda P, Reis J, Rizzato S, Giorgi Mariani M, Mauri M. Clinical subtypes of severe bipolar mixed states. J Affect Disord 2013;151:1076-82.

[42] Nery FG, Miranda-Scippa A, Nery-Fernandes F, Kapczinski F, Lafer B. Prevalence and clinical correlates of alcohol use disorders among bipolar disorder patients: results from the Brazilian Bipolar Research Network. Compr Psychiatry 2014;55:1116-21.

[43] Asaad T, Okasha T, Ramy H, Fekry M, Zaki N, Azzam H, et al. Correlates of psychiatric co-morbidity in a sample of Egyptian patients with bipolar disorder. J Affect Disord 2014;166:347-52. 
[44] Baek JH, Cha B, Moon E, Ha TH, Chang JS, Kim JH, et al. The effects of ethnic, social and cultural factors on axis I comorbidity of bipolar disorder: results from the clinical setting in Korea. J Affect Disord 2014;166:264-9.

[45] Eich D, Gamma A, Malti T, Vogt Wehrli M, Liebrenz M, Seifritz E, et al. Temperamental differences between bipolar disorder, borderline personality disorder, and attention deficit/hyperactivity disorder: some implications for their diagnostic validity. $\mathrm{J}$ Affect Disord 2014;169:101-4.

[46] Woldeyohannes HO, Soczynska JK, Maruschak NA, Syeda K, Wium-Andersen IK, Lee Y, et al. Binge eating in adults with mood disorders: Results from the International Mood Disorders Collaborative Project. Obes Res Clin Pract 2015.

[47] McElroy, Crow S, Blom TJ, Biernacka JM, Winham SJ, Geske J, et al. Prevalence and correlates of DSM-5 eating disorders in patients with bipolar disorder. J Affect Disord 2016;191:216-21.

[48] Holtzman JN, Miller S, Hooshmand F, Wang PW, Chang KD, Goffin KC, et al. Gender by onset age interaction may characterize distinct phenotypic subgroups in bipolar patients. J Psychiatr Res 2016;76:128-35.

[49] Martin K, Woo J, Timmins V, Collins J, Islam A, Newton D, et al. Binge eating and emotional eating behaviors among adolescents and young adults with bipolar disorder. $\mathrm{J}$ Affect Disord 2016;195:88-95.

[50] Smink FRE, van Hoeken D, Hoek HW. Epidemiology of Eating Disorders: Incidence, Prevalence and Mortality Rates. Curr Psychiatry Rep 2012;14:406-14.

[51] Zerwas S, Larsen JT, Petersen L, Thornton LM, Mortensen PB, Bulik CM. The incidence of eating disorders in a Danish register study: Associations with suicide risk and mortality. J Psychiatr Res 2015;65:16-22.

[52] Serrano-Troncoso E, Cañas L, Carbonell X, Carulla M, Palma C, Matalí J, et al. Diagnostic Distribution of eating disorders: Comparison between DSMIV- TR and DSM-5. Actas Esp Psiquiatr 2017;45:32-8.

[53] Hudson JI, Pope HG, Jonas JM, Yurgelun-Todd D. Phenomenologic relationship of eating disorders to major affective disorder. Psychiatry Res 1983;9:345-54.

[54] Piran N, Kennedy S, Garfinkel PE, Owens M. Affective disturbance in eating disorders. J Nerv Ment Dis 1985;173:395-400.

[55] Walsh BT, Roose SP, Glassman AH, Gladis M, Sadik C. Bulimia and depression. Psychosom Med 1985;47:123-31.

[56] Powers PS, Coovert DL, Brightwell DR, Stevens BA. Other psychiatric disorders among bulimic patients. Compr Psychiatry 1988;29:503-8.

[57] Herzog DB, Keller MB, Sacks NR, Yeh CJ, Lavori PW. Psychiatric comorbidity in treatment-seeking anorexics and bulimics. J Am Acad Child Adolesc Psychiatry 1992;31:810-8.

[58] Braun DL, Sunday SR, Halmi KA. Psychiatric comorbidity in patients with eating disorders. Psychol Med 1994;24:859-67.

[59] Brewerton TD, Lydiard RB, Herzog DB, Brotman AW, O'Neil PM, Ballenger JC. Comorbidity of axis I psychiatric disorders in bulimia nervosa. J Clin Psychiatry 1995;56:7780 . 
[60] Iwasaki Y, Matsunaga H, Kiriike N, Tanaka H, Matsui T. Comorbidity of axis I disorders among eating-disordered subjects in Japan. Compr Psychiatry 2000;41:454-60.

[61] Eddy KT, Keel PK, Dorer DJ, Delinsky SS, Franko DL, Herzog DB. Longitudinal comparison of anorexia nervosa subtypes. Int J Eat Disord 2002;31:191-201.

[62] McElroy, Arnold LM, Shapira NA, Keck PE, Rosenthal NR, Karim MR, et al. Topiramate in the treatment of binge eating disorder associated with obesity: a randomized, placebo-controlled trial. Am J Psychiatry 2003;160:255-61.

[63] Joyce PR, Luty SE, McKenzie JM, Mulder RT, McIntosh VV, Carter FA, et al. Bipolar II disorder: personality and outcome in two clinical samples. Aust N Z J Psychiatry 2004;38:433-8.

[64] Nagata T, Yamada H, Teo AR, Yoshimura C, Kodama Y, van Vliet I. Using the mood disorder questionnaire and bipolar spectrum diagnostic scale to detect bipolar disorder and borderline personality disorder among eating disorder patients. BMC Psychiatry 2013;13:69.

[65] Campos R, dos Santos JR, Cordás T, Angst J, Moreno R. Occurrence of bipolar spectrum disorder and comorbidities in women with eating disorders. Int J Bipolar Disord 2013;1:25.

[66] Rodríguez Guarín M, Rodríguez Malagón N, Gempeler Rueda J, Garzón DF. Factores asociados con intento de suicidio y comportamientos de autolesión no suicida en pacientes con trastornos del comportamiento alimentario. Rev Colomb Psiquiatr 2013;43:19-26.

[67] Franko DL, Keshaviah A, Eddy KT, Krishna M, Davis MC, Keel PK, et al. A longitudinal investigation of mortality in anorexia nervosa and bulimia nervosa. Am $\mathrm{J}$ Psychiatry 2013;170:917-25.

[68] Lähteenmäki S, Saarni S, Suokas J, Saarni S, Perälä J, Lönnqvist J, et al. Prevalence and correlates of eating disorders among young adults in Finland. Nord J Psychiatry 2014;68:196-203.

[69] Ulfvebrand S, Birgegård A, Norring C, Högdahl L, von Hausswolff-Juhlin Y. Psychiatric comorbidity in women and men with eating disorders results from a large clinical database. Psychiatry Res 2015;230:294-9.

[70] Kask J, Ekselius L, Brandt L, Kollia N, Ekbom A, Papadopoulos FC. Mortality in Women With Anorexia Nervosa: The Role of Comorbid Psychiatric Disorders. Psychosom Med 2016.

[71] Gershon ES, Schreiber JL, Hamovit JR, Dibble ED, Kaye W, Nurnberger JI, et al. Clinical findings in patients with anorexia nervosa and affective illness in their relatives. Am J Psychiatry 1984;141:1419-22.

[72] Stern SL, Dixon KN, Nemzer E, Lake MD, Sansone RA, Smeltzer DJ, et al. Affective disorder in the families of women with normal weight bulimia. Am J Psychiatry 1984;141:1224-7.

[73] Hudson JI, Pope HG, Yurgelun-Todd D, Jonas JM, Frankenburg FR. A controlled study of lifetime prevalence of affective and other psychiatric disorders in bulimic outpatients. Am J Psychiatry 1987;144:1283-7.

[74] Hudson JI, Pope HG, Wurtman J, Yurgelun-Todd D, Mark S, Rosenthal NE. Bulimia in obese individuals. Relationship to normal-weight bulimia. J Nerv Ment Dis 1988;176:14452.

[75] Toner BB, Garfinkel PE, Garner DM. Affective and anxiety disorders in the long-term 
follow-up of anorexia nervosa. Int J Psychiatry Med 1988;18:357-64.

[76] Keck PE, Pope HG, Hudson JI, McElroy SL, Yurgelun-Todd D, Hundert EM. A controlled study of phenomenology and family history in outpatients with bulimia nervosa. Compr Psychiatry 1990;31:275-83.

[77] Halmi KA, Eckert E, Marchi P, Sampugnaro V, Apple R, Cohen J. Comorbidity of psychiatric diagnoses in anorexia nervosa. Arch Gen Psychiatry 1991;48:712-8.

[78] Yanovski SZ, Nelson JE, Dubbert BK, Spitzer RL. Association of binge eating disorder and psychiatric comorbidity in obese subjects. Am J Psychiatry 1993;150:1472-9.

[79] Råstam M, Gillberg IC, Gillberg C. Anorexia nervosa 6 years after onset: Part II. Comorbid psychiatric problems. Compr Psychiatry 1995;36:70-6.

[80] Bushnell JA, Wells JE, McKenzie JM, Hornblow AR, Oakley-Browne MA, Joyce PR. Bulimia comorbidity in the general population and in the clinic. Psychol Med 1994;24:60511.

[81] Grilo CM, Levy KN, Becker DF, Edell WS, McGlashan TH. Comorbidity of DSMIII-R axis I and II disorders among female inpatients with eating disorders. Psychiatr Serv Wash DC 1996;47:426-9.

[82] Lilenfeld LR, Kaye WH, Greeno CG, Merikangas KR, Plotnicov K, Pollice C, et al. A controlled family study of anorexia nervosa and bulimia nervosa: psychiatric disorders in first-degree relatives and effects of proband comorbidity. Arch Gen Psychiatry 1998;55:60310.

[83] Telch CF, Stice E. Psychiatric comorbidity in women with binge eating disorder: prevalence rates from a non-treatment-seeking sample. J Consult Clin Psychol 1998;66:76876.

[84] Ivarsson T, Råstam M, Wentz E, Gillberg IC, Gillberg C. Depressive disorders in teenage-onset anorexia nervosa: A controlled longitudinal, partly community-based study. Compr Psychiatry 2000;41:398-403.

[85] Fontenelle LF, VÍtor Mendlowicz M, de Menezes GB, Papelbaum M, Freitas SR, Godoy-Matos A, et al. Psychiatric comorbidity in a Brazilian sample of patients with bingeeating disorder. Psychiatry Res 2003;119:189-94.

[86] Javaras KN, Pope HG, Lalonde JK, Roberts JL, Nillni YI, Laird NM, et al. Cooccurrence of binge eating disorder with psychiatric and medical disorders. J Clin Psychiatry 2008;69:266-73.

[87] Aspen V, Weisman H, Vannucci A, Nafiz N, Gredysa D, Kass AE, et al. Psychiatric co-morbidity in women presenting across the continuum of disordered eating. Eat Behav 2014;15:686-93.

[88] Godart, Radon L, Curt F, Duclos J, Perdereau F, Lang F, et al. Mood disorders in eating disorder patients: Prevalence and chronology of ONSET. J Affect Disord 2015;185:115-22.

[89] Tseng M-CM, Chang C-H, Chen K-Y, Liao S-C, Chen H-C. Prevalence and correlates of bipolar disorders in patients with eating disorders. J Affect Disord 2016;190:599-606.

[90] Welch E, Jangmo A, Thornton LM, Norring C, von Hausswolff-Juhlin Y, Herman $\mathrm{BK}$, et al. Treatment-seeking patients with binge-eating disorder in the Swedish national registers: clinical course and psychiatric comorbidity. BMC Psychiatry 2016;16. 
[91] Marzola E, Fassino S, Amianto F, Abbate-Daga G. Affective temperaments in anorexia nervosa: The relevance of depressive and anxious traits. J Affect Disord 2017;218:23-9.

[92] Merikangas KR, Jin R, He J-P, Kessler RC, Lee S, Sampson NA, et al. Prevalence and Correlates of Bipolar Spectrum Disorder in the World Mental Health Survey Initiative. Arch Gen Psychiatry 2011;68:241-51.

[93] Specker S, de Zwaan M, Raymond N, Mitchell J. Psychopathology in subgroups of obese women with and without binge eating disorder. Compr Psychiatry 1994;35:185-90.

[94] Liu X, Kelsoe JR, Greenwood TA. A genome-wide association study of bipolar disorder with comorbid eating disorder replicates the SOX2-OT region. J Affect Disord 2016;189:141-9.

[95] Becker DF, Grilo CM. Comorbidity of mood and substance use disorders in patients with binge-eating disorder: Associations with personality disorder and eating disorder pathology. J Psychosom Res 2015;79:159-64.

[96] Morgan, Reid F, Lacey JH. The SCOFF questionnaire: assessment of a new screening tool for eating disorders. BMJ 1999;319:1467-8.

[97] McElroy SL, Crow S, Blom TJ, Cuellar-Barboza AB, Prieto ML, Veldic M, et al. Clinical features of bipolar spectrum with binge eating behaviour. J Affect Disord 2016;201:95-8.

[98] Kluge M, Schuld A, Himmerich H, Dalal M, Schacht A, Wehmeier PM, et al. Clozapine and olanzapine are associated with food craving and binge eating: results from a randomized double-blind study. J Clin Psychopharmacol 2007;27:662-6.

[99] Bould H, Koupil I, Dalman C, DeStavola B, Lewis G, Magnusson C. Parental mental illness and eating disorders in offspring. Int J Eat Disord 2015;48:383-91.

[100] Mantere O, Isometsä E, Ketokivi M, Kiviruusu O, Suominen K, Valtonen HM, et al. A prospective latent analyses study of psychiatric comorbidity of DSM-IV bipolar I and II disorders: Psychiatric comorbidity of bipolar I and II. Bipolar Disord 2010;12:271-84.

[101] Torrent C, Amann B, Sánchez-Moreno J, Colom F, Reinares M, Comes M, et al. Weight gain in bipolar disorder: pharmacological treatment as a contributing factor. Acta Psychiatr Scand 2008;118:4-18.

[102] Adida M, Jollant F, Clark L, Besnier N, Guillaume S, Kaladjian A, et al. Trait-related decision-making impairment in the three phases of bipolar disorder. Biol Psychiatry 2011;70:357-65.

[103] Guillaume S, Gorwood P, Jollant F, Van den Eynde F, Courtet P, Richard-Devantoy S. Impaired decision-making in symptomatic anorexia and bulimia nervosa patients: a metaanalysis. Psychol Med 2015;45:3377-91. 


\section{Figure 1. Flow Chart}

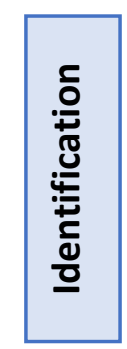

Documents from the Pubmed search

$$
(n=6829)
$$

Articles excluded because

of language $(n=340)$

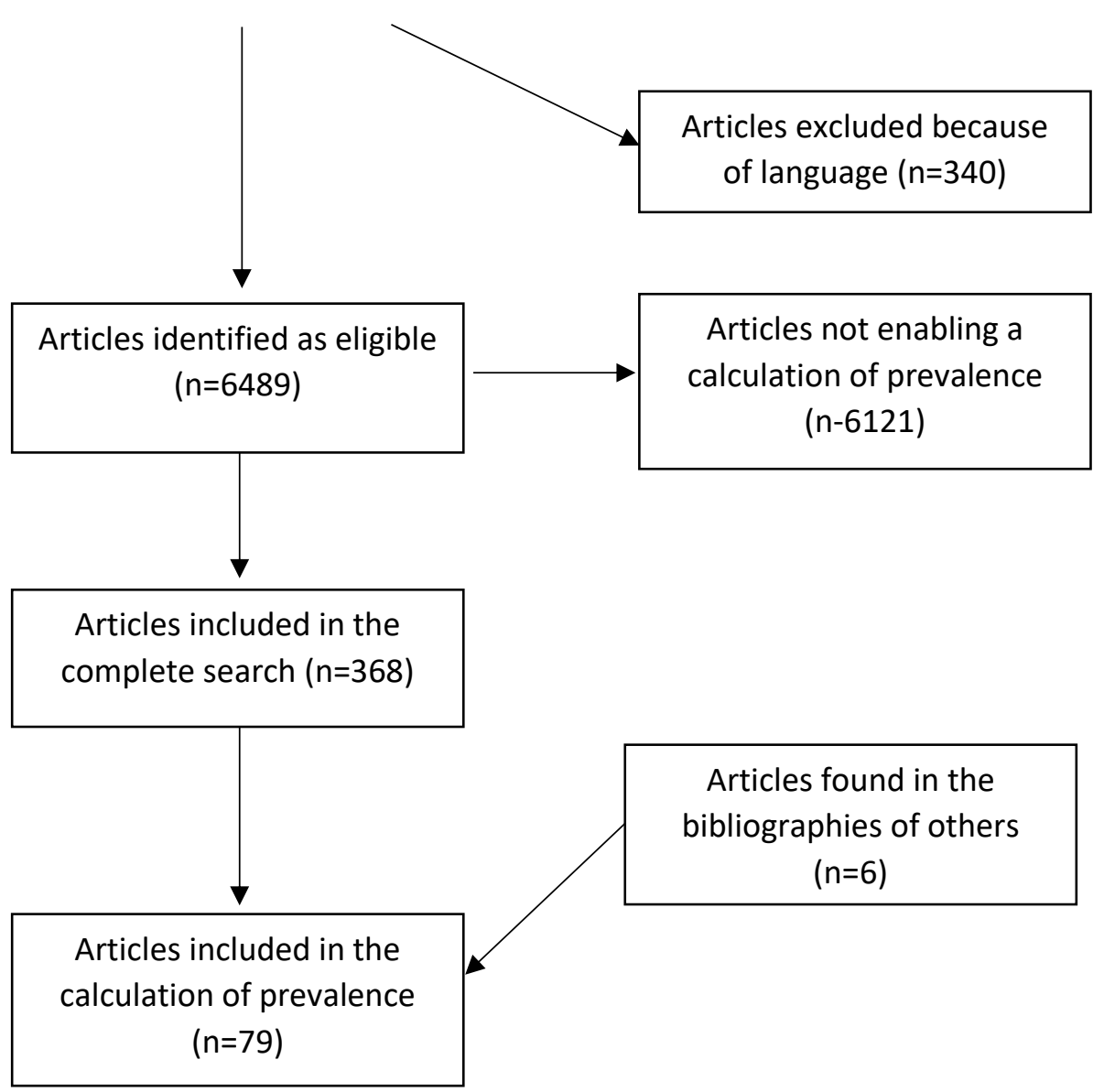




\section{Lifetime prevalence studies on ED among patients presenting a BD}
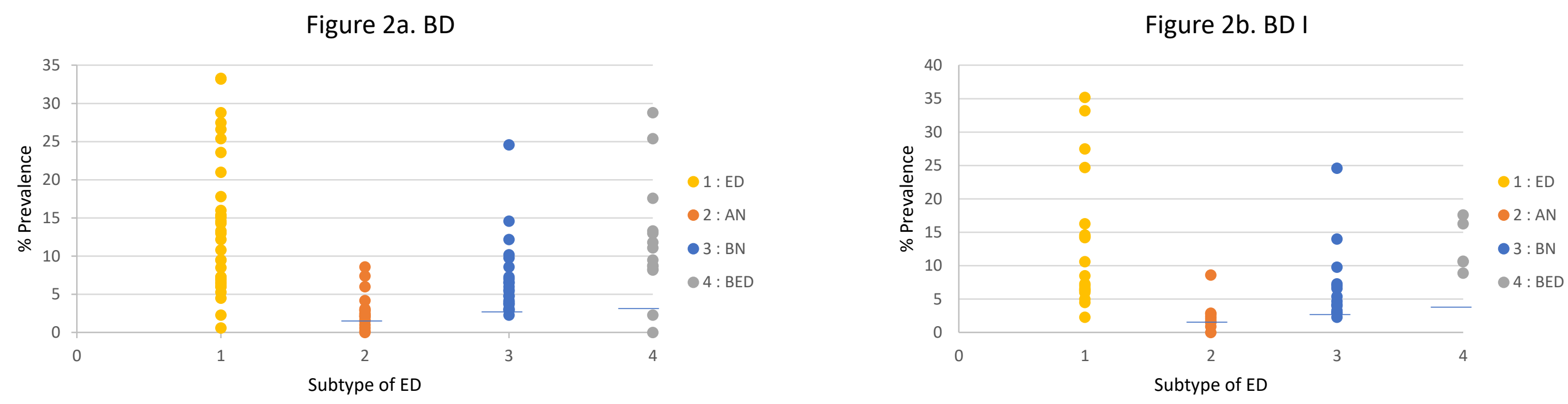

Figure 2c. BD II

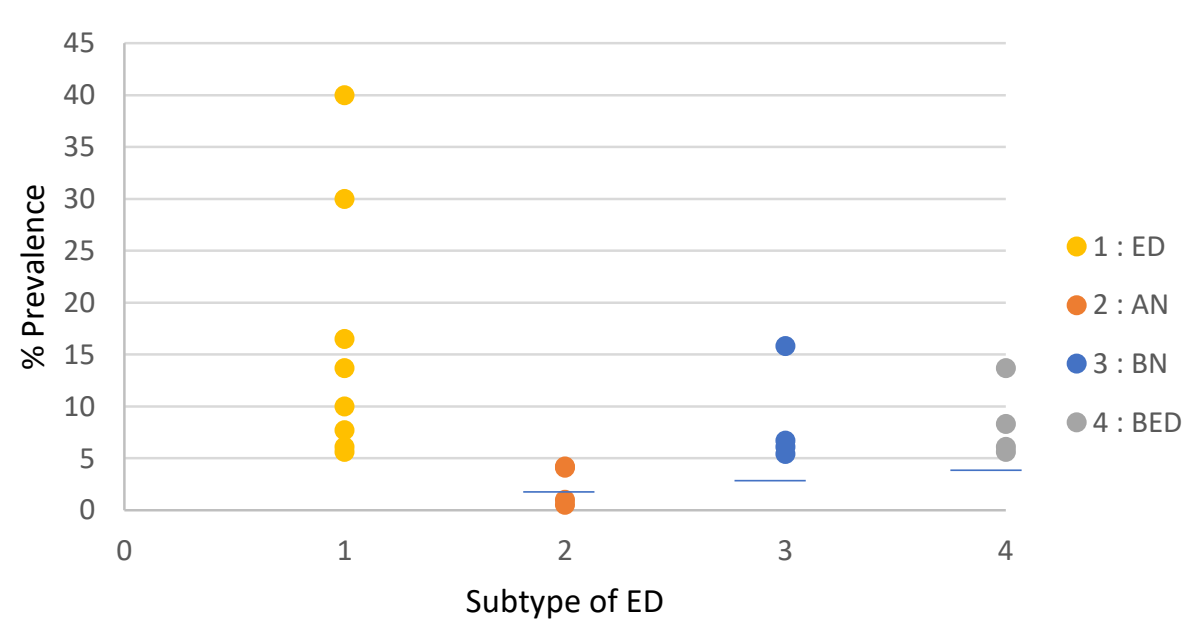

Approximate prevalence in the general population

$1 \mathrm{dot}=1 \mathrm{study}$ 


\section{Lifetime prevalence studies on BD among patients presenting an ED}

Figure 3a. ED

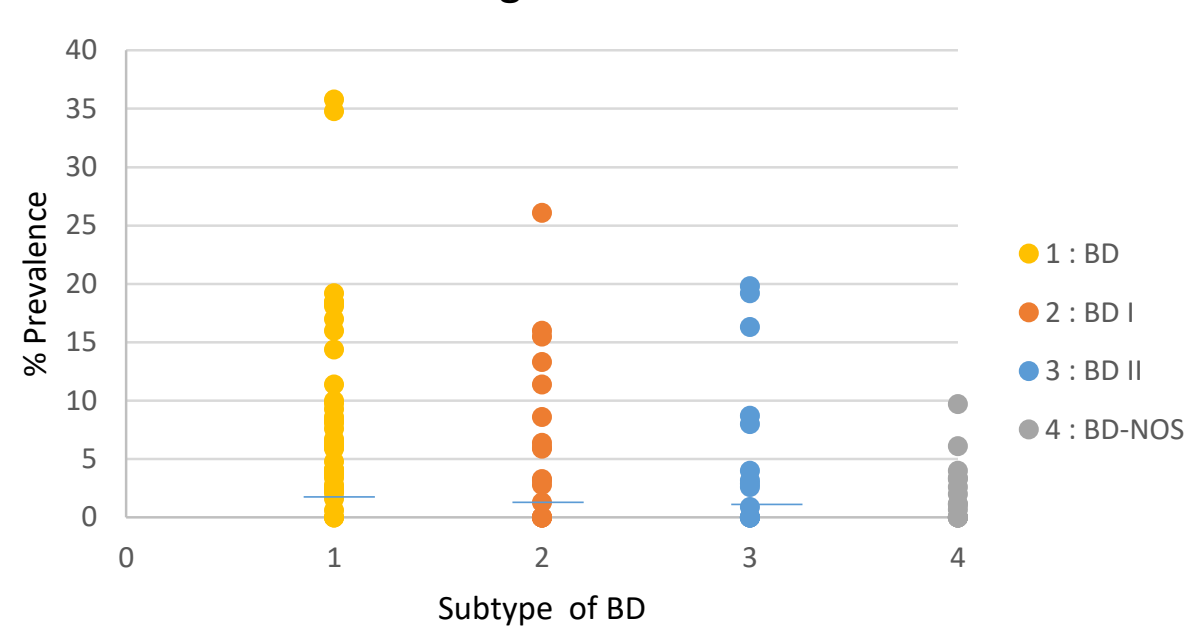

Figure $3 \mathrm{c}$. BN

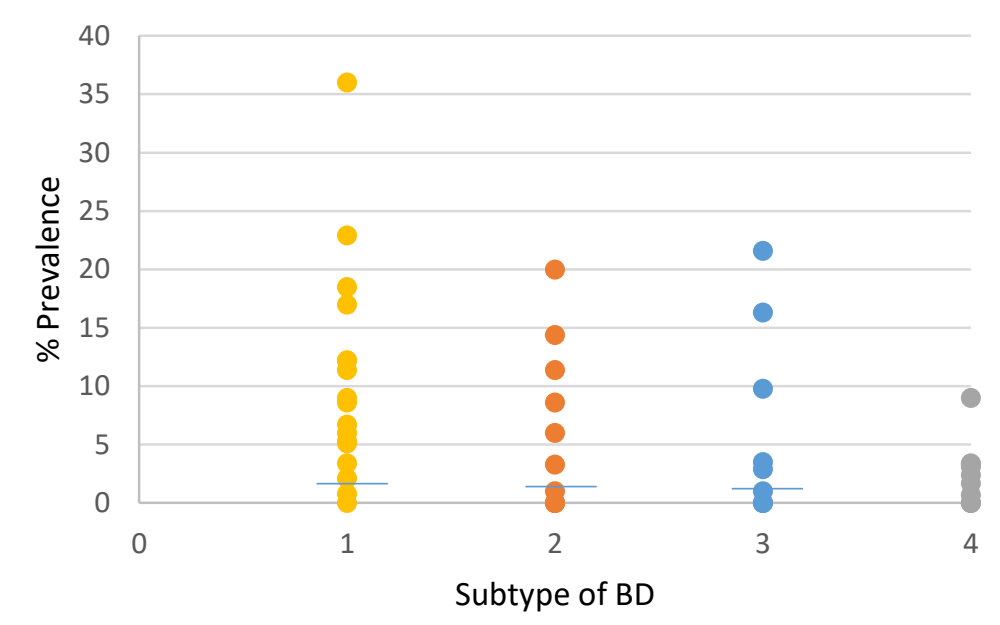

Figure 3b. AN

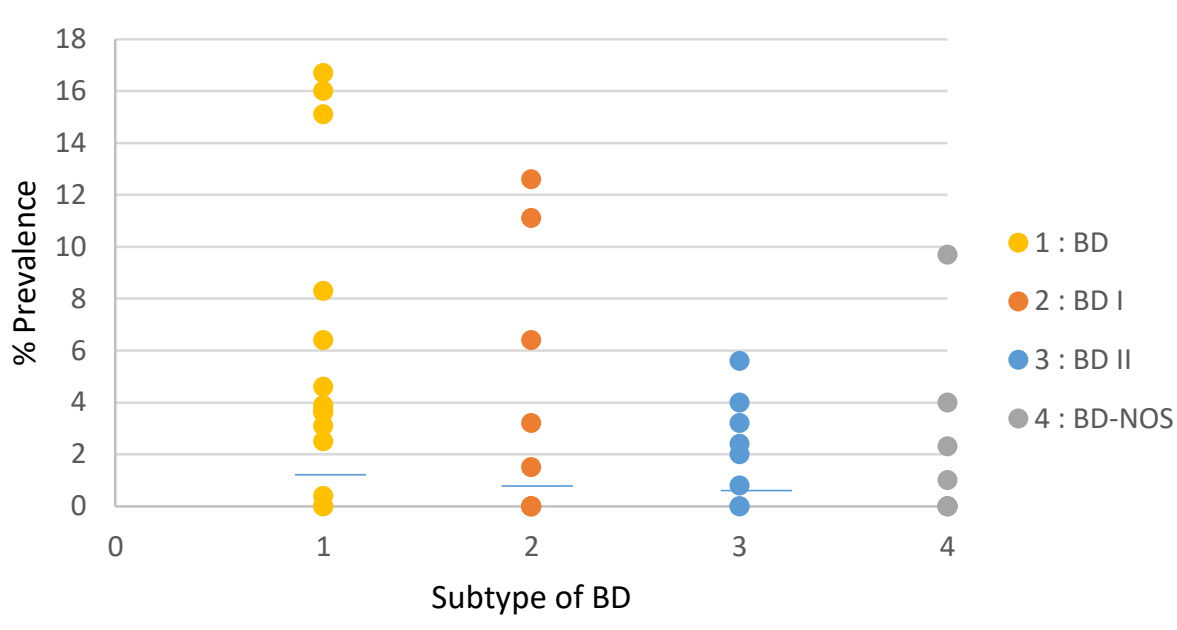

Figure 3d. BED

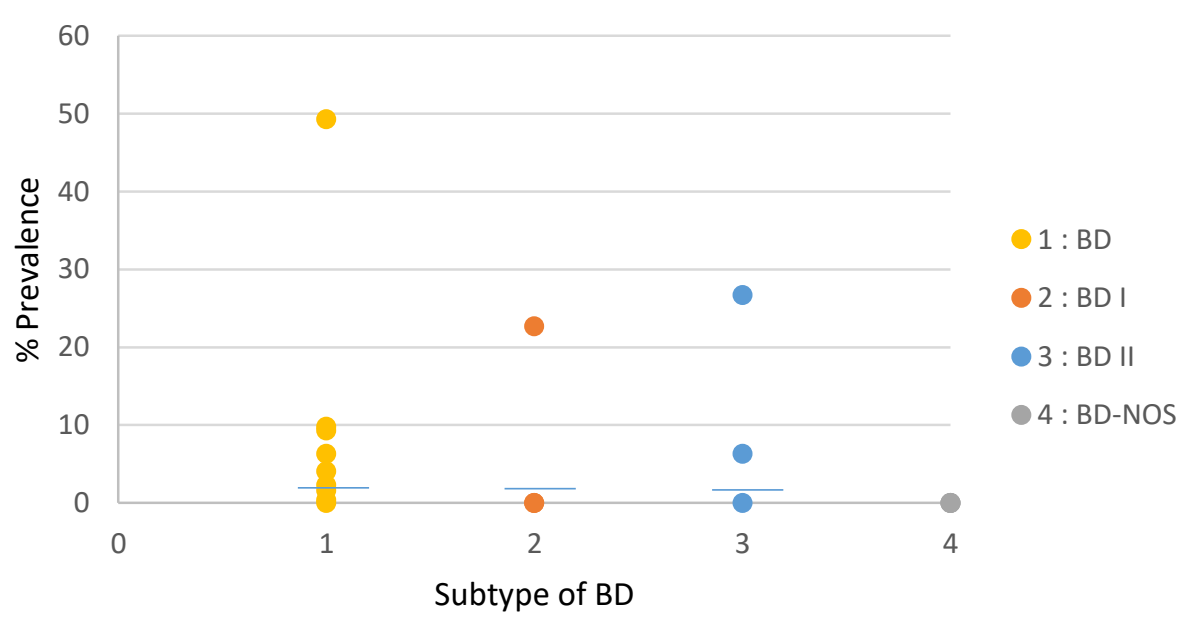

Approximate prevalence in the general population 


\section{Lifetime prevalence studies on BD among patients presenting AN}
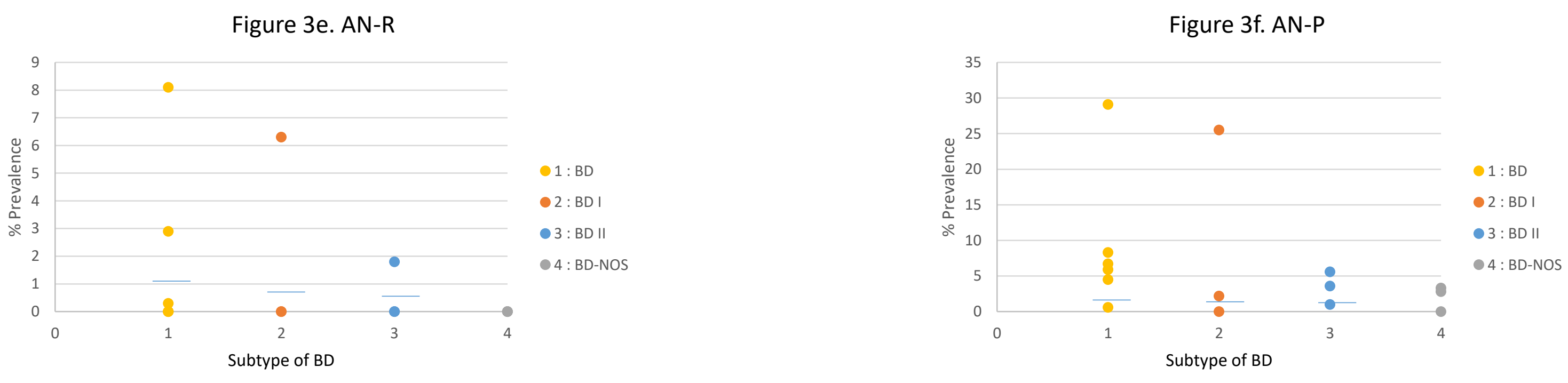

Approximate prevalence in the general population

$1 \mathrm{dot}=1$ study 


\begin{tabular}{|c|c|c|c|c|c|c|c|c|c|}
\hline $\begin{array}{l}\text { Study } \\
\text { Author, year } \\
\text { [reference] }\end{array}$ & $\begin{array}{l}\text { Instruments } \\
\text { Criteria }\end{array}$ & Population & $\% \mathrm{~F}$ & Age & $\begin{array}{l}\text { Type of ED } \\
\text { assessed }\end{array}$ & $\begin{array}{l}\text { Prevalence } \\
\text { BD among ED } \\
\text { subjects }\end{array}$ & $\begin{array}{l}\text { Prevalence BD } \\
\text { among non-ED } \\
\text { subjects } \\
\%(\mathrm{~N})\end{array}$ & $\begin{array}{l}\text { Prevalence } \\
\text { ED among BD } \\
\text { subjects } \\
\%(\mathrm{~N})\end{array}$ & $\begin{array}{l}\text { Prevalence } \\
\text { ED among } \\
\text { non-BD } \\
\text { subjects \% } \\
\text { (N) }\end{array}$ \\
\hline $\begin{array}{l}\text { Fogarty et coll. } \\
\text { [11] }\end{array}$ & $\begin{array}{l}\text { DIS } \\
\text { DSM-III }\end{array}$ & $\begin{array}{l}3258 \\
\text { inhabitants of } \\
\text { Edmonton } \\
\text { Canada }\end{array}$ & 59 & $>18$ & AN & 0 (NS) & $\begin{array}{l}0.6 \% \\
\text { ( } 22 \text { manic } \\
\text { episodes) }\end{array}$ & $0 \%(\mathrm{NS})$ & $\begin{array}{l}0,1 \% \\
(2 \mathrm{AN})\end{array}$ \\
\hline Angst et coll [12] & $\begin{array}{l}\text { SPIKE } \\
\text { DSM-IV }\end{array}$ & $\begin{array}{l}4547 \\
\text { inhabitants of } \\
\text { Zurich }\end{array}$ & ND & $19-20$ & $\begin{array}{l}\text { BH (4 } \\
\text { episodes } \\
\text { per year }\end{array}$ & ND & ND & $\begin{array}{l}12.8 \%(5) \\
\text { Hypomania } \\
14.3 \%(8) \\
\text { manic } \\
\text { symptoms } \\
(\mathrm{p}=0,06)\end{array}$ & $4.7 \%$ (11) $\mathrm{BH}$ \\
\hline $\begin{array}{l}\text { Lewinsohn et } \\
\text { coll. [13] }\end{array}$ & $\begin{array}{l}\text { K-SAD } \\
\text { DSM-III-R }\end{array}$ & 810 & 52 & 16.6 & $\begin{array}{l}23 \mathrm{ED}-\mathrm{NS} \\
19 \mathrm{ED}\end{array}$ & $\begin{array}{l}\text { BD } 0 \% \text { among } \\
\text { ED and 4,3\% } \\
\text { (1) ED-NS } \\
\text { BD-NS 26,3\% } \\
\text { (5) among ED } \\
\text { and 21,7\% (5) } \\
\text { among ED-NS }\end{array}$ & $\begin{array}{l}\text { BD 1,2\% (9) } \\
\text { BD-NS 3,8\% (29) }\end{array}$ & ND & ND \\
\hline $\begin{array}{l}\text { Lewinsohn et } \\
\text { coll. [14] }\end{array}$ & $\begin{array}{l}\text { K-SAD } \\
\text { DSM-III-R }\end{array}$ & 1704 & 52,1 & 16.6 & $\begin{array}{l}23 \text { ED-NS } \\
13 \text { ED (AN } \\
\text { or BN) }\end{array}$ & $\begin{array}{l}\text { BD-NS } \\
17.4 \%(4) \\
\text { OR : } 4.8(1,1- \\
20,4) \text { among } \\
\text { ED NS } \\
\text { TB 0\% chez } \\
\text { TCA-NS NS }\end{array}$ & $\begin{array}{l}\text { BD 0,88 \% (15) } \\
\text { BD-NS 4,4\% (75) }\end{array}$ & $\begin{array}{l}\text { ED : 4\% (3) } \\
\text { among BD-NS } \\
\text { OR } 6.7(1,2- \\
37,8) \\
\text { TCA-NS ND }\end{array}$ & $\begin{array}{l}0,76 \%(13) \text { ED - } \\
\text { NS } \\
\text { ED 1,3\% (23) }\end{array}$ \\
\hline $\begin{array}{l}\text { Hudson et coll. } \\
\text { [15] }\end{array}$ & $\begin{array}{l}\text { CIDI } \\
\text { DSM-IV }\end{array}$ & $\begin{array}{l}2980 \\
\text { USA }\end{array}$ & $59 \%$ & $>18$ & $\begin{array}{l}23 \mathrm{AN} \\
52 \mathrm{BN} \\
115 \mathrm{BH} \\
46 \mathrm{BH}-\mathrm{NS} \\
192 \text { any B- } \\
\text { ED }\end{array}$ & $\begin{array}{l}\text { BD } 1 \text { or } 2 \\
3 \% \text { AN (NS) } \\
17,7 \% \text { BN } \\
\text { (OR: } 4.7(2,1- \\
10,8)) \\
12,5 \% \text { BH } \\
(\mathrm{OR} 3,6(2,1- \\
6,3)) \\
10,5 \% \text { BH- } \\
\text { NS(NS) } \\
12 \% \text { Any B-ED } \\
3,5(2,0-6,1)\end{array}$ & ND & ND & $\begin{array}{l}\text { AN: } 0,6 \% \\
\text { BN: } 1,0 \% \\
\text { BH: } 2,8 \% \\
\text { BH-NS:1,2\% } \\
\text { Any B-ED: } \\
4,5 \%\end{array}$ \\
\hline $\begin{array}{l}\text { Swanson et coll } \\
{[16]}\end{array}$ & $\begin{array}{l}\text { CIDI } \\
\text { DSM-IV }\end{array}$ & 10123 & ND & $13-18$ & $\mathrm{~N}$ & $\begin{array}{l}2,1 \% \text { BD } 1 \text { or } 2 \\
\text { among AN (NS) } \\
8,1 \% \text { BD } 1 \text { or } 2 \\
\text { among AN NS } \\
\text { (NS) } \\
18,5 \% \text { BD } 1 \text { or } \\
2 \text { among BN } \\
\text { (AOR: } 7.3 \text { (3.1- } \\
17.2) \text { ) } \\
9 \% \text { BD } 1 \text { or } 2 \\
\text { among BH } \\
\text { (AOR } 3.0(1.5- \\
5.7) \text { ), } \\
2,6 \% \text { BH-NS } \\
\text { (NS) }\end{array}$ & $2,8 \%$ & ND & $\begin{array}{l}0,3 \% \text { AN, } \\
0,8 \% \text { AN-NS, } \\
0.9 \% \text { BN, } \\
1,6 \% \text { BH, } \\
2,5 \% \text { BH-NS } \\
\text { i.e. 4,5\% ED }\end{array}$ \\
\hline
\end{tabular}

Significant differences between the general population and the ED population for the prevalence of BD (and vice versa) are given as odds ratios (OR) or adjusted odds ratios (AOR), otherwise NS is specified

AN : anorexia nervosa; Any B-ED: any ED with bulimic episodes; infra diagnostic BD: defined as having had a distinct period of abnormal mood, persistent, marked, expansive or irritable, in addition to having one or several manic symptoms, but never having met the full criteria for bipolar disorder; BN: bulimia nervosa; CIDI: Composite International Diagnostic Interview; DIS: Diagnostic Interview Schedule; DSM: Diagnostic and Statistical Manual of Mental Disorders; $\mathrm{BH}$ : bulimic hyperphagia; BH-NS : bulimic episodes at least twice a week over several months with loss of control, without meeting the full criteria for bulimic hyperphagia; ND: no data available; SPIKE: structured psychopathological interview and rating of the social consequences of psychic disturbances for epidemiology; ED: Eating Disorders BD: Bipolar Disorder; BDI ; type I bipolar disorder; BDII: type II bipolar disorder; ED-NS: cases are generally defined by refusal to maintain adequate weight ( $85 \%$ of the norm) for AN and by the presence of recurrent compulsive eating behaviours for BN without having sufficient other ED symptoms to meet the diagnostic criteria; YMRS: Young Mania Rating Scale 


\begin{tabular}{|c|c|c|c|c|c|c|c|c|c|c|}
\hline $\begin{array}{c}\text { Studies } \\
\text { Author, year [reference] }\end{array}$ & $\begin{array}{l}\text { Instruments, } \\
\text { Criteria }\end{array}$ & Patients & $\begin{array}{l}\sum_{\tilde{E}}^{n} \\
\tilde{E}\end{array}$ & 品 & $\mathrm{N}$ & $F \%$ & $\begin{array}{l}\text { ED } \\
N(\%)\end{array}$ & $\begin{array}{l}\text { AN } \\
N(\%)\end{array}$ & $\begin{array}{l}\text { BN } \\
N(\%)\end{array}$ & $\begin{array}{c}\mathrm{BH} \\
\mathrm{N}(\%)\end{array}$ \\
\hline $\begin{array}{l}\text { Strakowski et coll. } 1992 \\
\text { [17] }\end{array}$ & SCID, DSM-III-R & $\begin{array}{l}\mathrm{BD}, 1^{\mathrm{st}} \text { manic } \\
\text { episode }\end{array}$ & $\mathrm{H}$ & 32 & 41 & 61 & $3(7.3 \%)$ & ND & $3(7.3 \%)$ & ND \\
\hline $\begin{array}{l}\text { Strakowski et coll. } 1993 \\
\text { [18] }\end{array}$ & $\begin{array}{l}\text { SCID, CGI, BPRS, } \\
\text { DSM-III-R }\end{array}$ & $\begin{array}{l}\text { BD } 1^{\text {st }} \text { manic } \\
\text { episode }\end{array}$ & $\mathrm{H}$ & 29 & 60 & 52 & $4(6.6 \%)$ & ND & $4(6.6 \%)$ & ND \\
\hline $\begin{array}{l}\text { McElroy et coll. } 1995 \\
\text { [19] }\end{array}$ & SCID, DSM-III-R & BD & $\mathrm{H}$ & 35 & 71 & 55 & $6(8.5 \%)$ & ND & ND & ND \\
\hline $\begin{array}{l}\text { Krüger, Shugar \& Cooke } \\
1996[20]\end{array}$ & $\begin{array}{l}\text { Semi-structured } \\
\text { interviews, SADS, } \\
\text { DSM-IV }\end{array}$ & $\begin{array}{l}\mathrm{BD} \\
\mathrm{BD} \text { I } \\
\mathrm{BD} \|\end{array}$ & A & 40 & $\begin{array}{l}61 \\
43 \\
18\end{array}$ & 63 & $\begin{array}{l}8(13 \%), \\
23(38 \%)^{*} \\
7(16.3 \%), \\
18(41.8 \%)^{*} \\
1(5.6 \%), \\
5(33.3 \%)^{*}\end{array}$ & ND & ND & $\begin{array}{l}8(13 \%), \\
23(38 \%)^{*} \\
7(16.3 \%), \\
18(41.8 \%)^{*} \\
1(5.6 \%) \\
5(33.3 \%)^{*}\end{array}$ \\
\hline $\begin{array}{l}\text { Schuckit et coll. } 1996 \\
\text { [21] }\end{array}$ & SAGA, DSM-III-R & BD & $\mathrm{M}$ & 40 & 14 & 100 & $1(7 \%)$ & 0 & $1(7 \%)$ & ND \\
\hline $\begin{array}{l}\text { Edmonds et coll. } 1998 \\
{[22]}\end{array}$ & DIGS, RDC, DSM-IV & $\begin{array}{l}\mathrm{BD} \\
\mathrm{BDI} \\
\mathrm{BD} \|\end{array}$ & A & 41 & $\begin{array}{l}55 \\
44 \\
11\end{array}$ & 47 & $4(7.3 \%)$ & $\mathrm{ND}$ & ND & ND \\
\hline $\begin{array}{l}\text { Cassano et coll. } 1998 \\
\text { [23] }\end{array}$ & SCID, DSM-IIII-R & BD, psychotic & $\mathrm{H}$ & 34 & 47 & 56 & $3(6 \%)$ & $1(2.1 \%)$ & $2(4.2 \%)$ & ND \\
\hline Pini et coll. 1999 [24] & SCID, DSM-III-R & BD, psychotic & $\mathrm{H}$ & 35 & 125 & 59 & $8(6.4 \%)$ & $3(2.4 \%)$ & $5(4 \%)$ & $\mathrm{ND}$ \\
\hline Vieta et coll. 2001 [25] & $\begin{array}{l}\text { SCID-II, RDC, } \\
\text { YMRS, DSM-IV }\end{array}$ & BDI & A & 40 & 129 & 59 & $3(2.3 \%)$ & ND & $3(2.3 \%)$ & ND \\
\hline $\begin{array}{l}\text { McElroy et coll. } 2001 \\
\text { [26] }\end{array}$ & SCID, DSM-III-R & $\begin{array}{l}\mathrm{BD} \\
\mathrm{BDI} \\
\mathrm{BD} \|\end{array}$ & A & 44 & $\begin{array}{l}288 \\
239 \\
49\end{array}$ & 56 & $\begin{array}{l}17(6 \%) \\
12(5 \%) \\
5(10 \%)\end{array}$ & $\begin{array}{l}6(2.1 \%) \\
4(1.7 \%) \\
2(4.1 \%)\end{array}$ & $\begin{array}{l}11(3.8 \%) \\
8(3.3 \%) \\
3(6.1 \%)\end{array}$ & ND \\
\hline $\begin{array}{l}\text { MacQueen et coll. } 2003 \\
\text { [27] }\end{array}$ & $\begin{array}{l}\text { SCID, YMRS, DSM- } \\
\text { IV }\end{array}$ & $\begin{array}{l}\mathrm{BD} \\
\mathrm{BDI} \\
\mathrm{BD} \|\end{array}$ & A & 40 & $\begin{array}{l}138 \\
97 \\
41\end{array}$ & 68 & $21(15.2 \%)$ & $4(2.9 \%)$ & $9(6.5 \%)$ & $12(8.7 \%)$ \\
\hline $\begin{array}{l}\text { Ramacciotti et coll. } \\
2005[28]\end{array}$ & $\begin{array}{l}\text { SCID, BEDCI, DSM- } \\
\text { IV }\end{array}$ & BDI & A & 40 & 51 & 43 & $14(27.5 \%)$ & ND & $5(9.8 \%)$ & $9(17.6 \%)$ \\
\hline Alciati et coll. 2007 [29] & $\begin{array}{l}\text { SCID, HCL-32 } \\
\text { QEWP-R, DSM-IV- } \\
\text { TR }\end{array}$ & $\begin{array}{l}\text { Obesity + pre- } \\
\text { bariatric } \\
\text { BD }\end{array}$ & A & 44 & 74 & 70 & $\begin{array}{l}11(13.3 \%) \\
21(25.3 \%)^{*}\end{array}$ & 0 & 0 & $\begin{array}{l}11(13.3 \%) \\
21(25.3 \%)^{*}\end{array}$ \\
\hline $\begin{array}{l}\text { Wildes, Marcus \& } \\
\text { Fagiolini } 2007 \text { [30] }\end{array}$ & $\begin{array}{l}\text { SCID, CGI-S-TB, } \\
\text { DSM-IV, }\end{array}$ & $\begin{array}{l}\text { BD } \\
\text { BD I } \\
\text { BD II } \\
\text { BD-NS } \\
\text { SAD BD }\end{array}$ & A & 42 & $\begin{array}{l}72 \\
\\
54 \\
\\
15 \\
2 \\
1\end{array}$ & 62 & $\begin{array}{l}17(23.6 \%) \\
26(36 \%)^{* *} \\
19(35.2 \%)^{* *} \\
6(40 \%)^{* *} \\
1(50 \%)^{* *} \\
0\end{array}$ & $\begin{array}{l}3(4.2 \%) \\
6(8.3 \%)^{* *} \\
\text { ND } \\
\text { ND } \\
\text { ND } \\
\text { ND }\end{array}$ & $\begin{array}{l}4(5.6 \%) \\
7(9.7 \%)^{* *} \\
\text { ND } \\
\text { ND } \\
\text { ND } \\
\text { ND }\end{array}$ & $\begin{array}{l}6(8.3 \%) \\
9(12.5 \%)^{* *} \\
\text { ND } \\
\text { ND } \\
\text { ND } \\
\text { ND }\end{array}$ \\
\hline $\begin{array}{l}\text { Wildes, Marcus \& } \\
\text { Fagiolini } 2008 \text { [31] }\end{array}$ & $\begin{array}{l}\text { SCID, BDVF, DSM- } \\
\text { IV, }\end{array}$ & $\begin{array}{l}\text { BD } \\
\text { BDS I } \\
\text { BD II } \\
\text { BD-NS }\end{array}$ & A & & $\begin{array}{l}81 \\
59 \\
17 \\
5\end{array}$ & 65 & $\begin{array}{l}17(21 \%) \\
\text { ND } \\
\text { ND } \\
\text { ND }\end{array}$ & $\begin{array}{l}6(7.4 \%)^{* *} \\
\text { ND } \\
\text { ND } \\
\text { ND }\end{array}$ & $\begin{array}{l}7(8.6 \%)^{* *} \\
\text { ND } \\
\text { ND } \\
\text { ND }\end{array}$ & $\begin{array}{l}9(11.1 \%)^{* *} \\
\text { ND } \\
\text { ND } \\
\text { ND }\end{array}$ \\
\hline Lunde et coll. 2009 [32] & DSM-IV & $\begin{array}{l}\text { Mood } \\
\text { disturbances } \\
\text { BD } \\
\text { MDE }\end{array}$ & $\mathrm{M}$ & 37 & $\begin{array}{l}201 \\
87 \\
814\end{array}$ & 69 & $\begin{array}{l}3(16 \%) \\
\text { ND } \\
\text { ND }\end{array}$ & $\begin{array}{l}12(6 \%) \\
22(12.9 \%) \\
* * * \\
\text { ND } \\
\text { ND }\end{array}$ & $\begin{array}{l}11(5.4 \%) \\
21(10.4 \%) \\
* * * \\
\text { ND } \\
\text { ND }\end{array}$ & $\begin{array}{l}\mathrm{ND} \\
\mathrm{ND} \\
\mathrm{ND}\end{array}$ \\
\hline $\begin{array}{l}\text { McElroy et coll. } 2011 \\
\text { [33] }\end{array}$ & SCID, DSM-IV & $\begin{array}{l}\mathrm{BD} \\
\mathrm{BD} \text { I } \\
\mathrm{BD} \text { II }\end{array}$ & A & 41 & $\begin{array}{l}875 \\
707 \\
168\end{array}$ & 56 & $\begin{array}{l}125(14.3 \%) \\
102(14.4 \%) \\
23(13.7 \%)\end{array}$ & $\begin{array}{l}27(3.1 \%) \\
\\
20(2.8 \%) \\
7(4.2 \%)\end{array}$ & $\begin{array}{l}42(4.8 \%) \\
\\
33(4.7 \%) \\
9(5.4 \%)\end{array}$ & $\begin{array}{l}77(8.8 \%) \\
\\
63(8.9 \%) \\
14(8.3 \%)\end{array}$ \\
\hline $\begin{array}{l}\text { Brietzke et coll. } 2011 \\
\text { [34] }\end{array}$ & SCID, DSM-IV & BD I & $A$ & 36 & 137 & 100 & $20(14.6 \%)$ & $4(2.9 \%)^{* *}$ & $4(2.9 \%)^{* *}$ & ND \\
\hline Schoofs et coll. 2011 & YMRS, DSM-IV & $\mathrm{BD}$ & $A$ & 37 & 52 & 100 & $15(28.8 \%)$ & 0 & 0 & $15(28.8 \%)$ \\
\hline
\end{tabular}




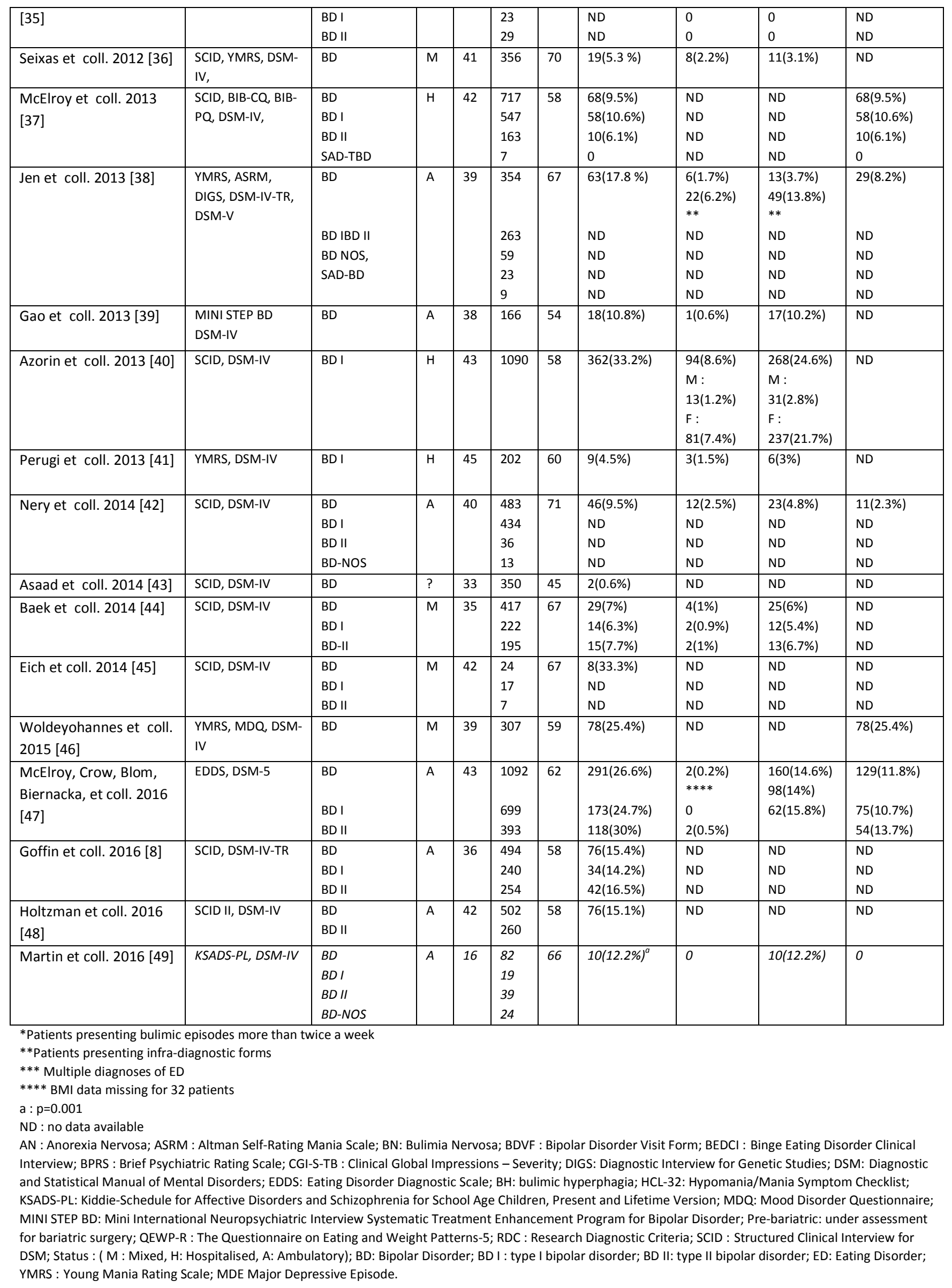




\begin{tabular}{|c|c|c|c|c|c|c|c|c|c|c|}
\hline $\begin{array}{c}\text { Studies } \\
\text { Author, year } \\
\text { [reference] }\end{array}$ & $\begin{array}{l}\text { Instruments, } \\
\text { Criteria }\end{array}$ & Patients & 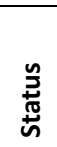 & $\underset{<}{\stackrel{80}{<}}$ & $N$ & $\begin{array}{l}\mathrm{F} \\
\%\end{array}$ & $\begin{array}{l}\text { BD } \\
\text { N (\%) }\end{array}$ & $\begin{array}{l}\mathrm{BD} \mathrm{I} \\
\mathrm{N}(\%)\end{array}$ & $\begin{array}{l}\text { BD II } \\
\text { N (\%) }\end{array}$ & $\begin{array}{l}\text { BD-NS } \\
\mathrm{N}(\%)\end{array}$ \\
\hline $\begin{array}{l}\text { Hudson et coll. } 1983 \\
\text { [53] }\end{array}$ & DIS, DSM-III & $\begin{array}{l}\text { ED } \\
\text { AN-R } \\
\text { AN-P } \\
\text { BN }\end{array}$ & $M$ & 28 & \begin{tabular}{|l|}
90 \\
16 \\
25 \\
49
\end{tabular} & 94 & $\begin{array}{l}13(14.4 \%) \\
\text { ND } \\
\text { ND } \\
\text { ND }\end{array}$ & $\begin{array}{l}12(13.3 \%) \\
\text { ND } \\
\text { ND } \\
\text { ND }\end{array}$ & $\begin{array}{l}0 \\
0 \\
0 \\
0\end{array}$ & $\begin{array}{l}1(1.1 \%) \\
\text { ND } \\
\text { ND } \\
\text { ND }\end{array}$ \\
\hline $\begin{array}{l}\text { Piran et coll. } 1985 \\
\text { [54] }\end{array}$ & SADS, DSM-III & $\begin{array}{l}\text { ED } \\
\text { AN } \\
\text { BN }\end{array}$ & M & 22 & \begin{tabular}{|l|}
49 \\
14 \\
33
\end{tabular} & 100 & $\begin{array}{l}3(6.1 \%) \\
0 \\
3(9 \%)\end{array}$ & $\begin{array}{l}0 \\
0 \\
0\end{array}$ & $\begin{array}{l}0 \\
0 \\
0\end{array}$ & $\begin{array}{l}3(6.1 \%) \\
0 \\
3(9 \%)\end{array}$ \\
\hline $\begin{array}{l}\text { Walsh et coll. } 1985 \\
\text { [55] }\end{array}$ & SADS, DSM-III et RDC & $\begin{array}{l}\mathrm{ED} \\
\mathrm{AN} \\
\mathrm{BN}\end{array}$ & $\mathrm{M}$ & 25 & \begin{tabular}{|l|}
50 \\
9 \\
41 \\
\end{tabular} & 100 & $\begin{array}{l}5(10 \%) \\
0 \\
5(12.2 \%) \\
\end{array}$ & $\begin{array}{l}0 \\
0 \\
0\end{array}$ & $\begin{array}{l}4(8 \%) \\
0 \\
4(9.8 \%)\end{array}$ & $\begin{array}{l}1(2 \%) \\
0 \\
1(2.4 \%)\end{array}$ \\
\hline $\begin{array}{l}\text { Powers et coll. } 1988 \\
\text { [56] }\end{array}$ & SCID, DSM-III-R & $\mathrm{BN}$ & A & 29 & 30 & 100 & $2(6.7 \%)$ & $1(3.3 \%)$ & 0 & $1(3.3 \%)$ \\
\hline $\begin{array}{l}\text { (Herzog et coll. 1992) } \\
\text { [57] }\end{array}$ & SADS, DSM-III-R & $\begin{array}{l}\text { ED } \\
\text { AN-R } \\
\text { AN-P } \\
\text { BN } \\
\end{array}$ & A & 24 & \begin{tabular}{|l|}
229 \\
41 \\
90 \\
98 \\
\end{tabular} & 100 & $\begin{array}{l}11(4.8 \%) \\
0 \\
6(6.7 \%) \\
5(5.1 \%) \\
\end{array}$ & $\begin{array}{l}3(1.3 \%) \\
0 \\
2(2.2 \%) \\
1(1 \%) \\
\end{array}$ & $\begin{array}{l}2(0.9 \%) \\
0 \\
1(1 \%) \\
1(1 \%) \\
\end{array}$ & $\begin{array}{l}6(2.6 \%) \\
0 \\
3(3.3 \%) \\
3(3.1 \%) \\
\end{array}$ \\
\hline $\begin{array}{l}\text { Braun, Sunday \& } \\
\text { Halmi } 1994 \text { [58] }\end{array}$ & SCID, DSM-III-R & $\begin{array}{l}\text { ED } \\
\text { AN-R } \\
\text { AN-P } \\
\text { BN }\end{array}$ & $\mathrm{H}$ & 25 & \begin{tabular}{|l|}
105 \\
34 \\
22 \\
49 \\
\end{tabular} & 100 & $\begin{array}{l}8(7.6 \%) \\
1(2.9 \%) \\
1(4.5 \%) \\
6(12.2 \%)\end{array}$ & $\begin{array}{l}N D \\
N D \\
N D \\
N D\end{array}$ & $\begin{array}{l}\text { ND } \\
\text { ND } \\
\text { ND } \\
\text { ND }\end{array}$ & $\begin{array}{l}\text { ND } \\
\text { ND } \\
\text { ND } \\
\text { ND }\end{array}$ \\
\hline $\begin{array}{l}\text { Brewerton et coll. } \\
1995[59]\end{array}$ & SCID, DSM-IV & $\mathrm{BN}$ & A & 28 & 59 & 100 & $2(3.4 \%)$ & ND & ND & $2(3.4 \%)$ \\
\hline $\begin{array}{l}\text { Iwasaki et coll. } 2000 \\
\text { [60] }\end{array}$ & SCID, DSM-III-R & $\begin{array}{l}\text { ED } \\
\text { AN-R } \\
\text { AN-P } \\
\text { BN } \\
\text { BH }\end{array}$ & A & 22 & \begin{tabular}{|l|}
171 \\
62 \\
36 \\
57 \\
16 \\
\end{tabular} & 100 & $\begin{array}{l}7(4.1 \%) \\
0 \\
3(8.3 \%) \\
3(5.3 \%) \\
1(6.3 \%)\end{array}$ & $\begin{array}{l}0 \\
0 \\
0 \\
0 \\
0\end{array}$ & $\begin{array}{l}5(2.9 \%) \\
0 \\
2(5.6 \%) \\
2(3.5 \%) \\
1(6.3 \%)\end{array}$ & $\begin{array}{l}2(1.2 \%) \\
0 \\
1(2.8 \%) \\
1(1.7 \%) \\
0\end{array}$ \\
\hline $\begin{array}{l}\text { Eddy et coll. } 2002 \\
\text { [61] }\end{array}$ & DSM-III-R & $\begin{array}{l}\text { ED } \\
\text { AN-R } \\
\text { AN-P }\end{array}$ & A & 22 & \begin{tabular}{|l|}
136 \\
51 \\
85 \\
\end{tabular} & 100 & $\begin{array}{l}5(3.7 \%) \\
0 \\
5(5.9 \%)\end{array}$ & $\begin{array}{l}\mathrm{ND} \\
\mathrm{ND} \\
\mathrm{ND}\end{array}$ & $\begin{array}{l}\mathrm{ND} \\
\mathrm{ND} \\
\mathrm{ND}\end{array}$ & $\begin{array}{l}\mathrm{ND} \\
\mathrm{ND} \\
\mathrm{ND}\end{array}$ \\
\hline $\begin{array}{l}\text { McElroy et coll. } 2003 \\
\text { [62] }\end{array}$ & SCID, DSM-IV & $\mathrm{BH}$ & A & 40 & 61 & 87 & $6(9.8 \%)^{* *}$ & ND & ND & $\mathrm{ND}$ \\
\hline $\begin{array}{l}\text { Joyce et coll. } 2004 \\
\text { [63] }\end{array}$ & SCID, DSM-III-R & $\mathrm{BN}$ & A & 31 & 135 & 100 & $23(17 \%)$ & (excluded) & $22(16.3 \%)$ & $1(0.7 \%)$ \\
\hline $\begin{array}{l}\text { Nagata et coll. } 2013 \\
\text { [64] }\end{array}$ & $\begin{array}{l}\text { SCID, MDQ, BSDS, } \\
\text { DSM-IV }\end{array}$ & $\begin{array}{l}\text { TCA } \\
\text { AN-R } \\
\text { AN-P } \\
\text { BN } \\
\text { ED-NOS }\end{array}$ & A & 29 & \begin{tabular}{|l|}
78 \\
11 \\
24 \\
27 \\
16
\end{tabular} & 100 & $\begin{array}{l}15(19.2 \%) \\
\text { ND } \\
\text { ND } \\
\text { ND } \\
\text { ND }\end{array}$ & $\begin{array}{l}0 \\
N D \\
N D \\
N D \\
N D\end{array}$ & $\begin{array}{l}15(19.2 \%) \\
\text { ND } \\
\text { ND } \\
\text { ND } \\
\text { ND }\end{array}$ & $\begin{array}{l}0 \\
\text { ND } \\
\text { ND } \\
\text { ND } \\
\text { ND }\end{array}$ \\
\hline $\begin{array}{l}\text { Campos et coll. } 2013 \\
\text { [65] }\end{array}$ & SCID, DSM-IV & ED & A & 28 & \begin{tabular}{|l|}
69 \\
\end{tabular} & 100 & $24(34.8 \%)$ & $18(26.1 \%)$ & $6(8.7 \%)$ & 0 \\
\hline $\begin{array}{l}\text { Rodríguez Guarín et } \\
\text { coll. } 2013 \text { [66] }\end{array}$ & DSM-IV & $\begin{array}{l}\text { ED } \\
\text { AN } \\
\text { BN } \\
\text { BH }\end{array}$ & A & 21 & $\begin{array}{l}908 \\
328 \\
327 \\
155 \\
\end{array}$ & 95 & $\begin{array}{l}\text { 167(18.4\%) } \\
\text { ND } \\
\text { ND } \\
\text { ND }\end{array}$ & $\begin{array}{l}\mathrm{ND} \\
\mathrm{ND} \\
\mathrm{ND} \\
\mathrm{ND}\end{array}$ & $\begin{array}{l}\mathrm{ND} \\
\mathrm{ND} \\
\mathrm{ND} \\
\mathrm{ND}\end{array}$ & $\begin{array}{l}\mathrm{ND} \\
\mathrm{ND} \\
\mathrm{ND} \\
\mathrm{ND}\end{array}$ \\
\hline $\begin{array}{l}\text { Franko et coll. } 2013 \\
{[67]}\end{array}$ & DSM-IV & $\begin{array}{l}\text { ED } \\
\text { AN-R } \\
\text { AN-P } \\
\text { BN } \\
\end{array}$ & A & 24 & \begin{tabular}{|l|}
186 \\
51 \\
85 \\
50 \\
\end{tabular} & 100 & $\begin{array}{l}15(8.1 \%) \\
\text { ND } \\
\text { ND } \\
\text { ND }\end{array}$ & $\begin{array}{l}\mathrm{ND} \\
\mathrm{ND} \\
\mathrm{ND} \\
\mathrm{ND}\end{array}$ & $\begin{array}{l}\mathrm{ND} \\
\mathrm{ND} \\
\mathrm{ND} \\
\mathrm{ND}\end{array}$ & $\begin{array}{l}\mathrm{ND} \\
\mathrm{ND} \\
\mathrm{ND} \\
\mathrm{ND}\end{array}$ \\
\hline $\begin{array}{l}\text { Lähteenmäki et coll. } \\
2014 \text { [68] }\end{array}$ & SCID, DSM-IV-TR & $\begin{array}{l}\text { ED } \\
\text { AN } \\
\text { BN }\end{array}$ & A & 27 & \begin{tabular}{|l|}
29 \\
10 \\
11 \\
\end{tabular} & 100 & $\begin{array}{l}0 \\
0 \\
0\end{array}$ & $\begin{array}{l}0 \\
0 \\
0\end{array}$ & $\begin{array}{l}0 \\
0 \\
0\end{array}$ & $\begin{array}{l}0 \\
0 \\
0\end{array}$ \\
\hline $\begin{array}{l}\text { Ulfvebrand et coll. } \\
2015 \text { [69] }\end{array}$ & $\begin{array}{l}\text { SCID, DSM-IV-TR, } \\
\text { DSM-5 }\end{array}$ & $\begin{array}{l}\text { ED } \\
\text { AN-R } \\
\text { AN-P } \\
\text { BN } \\
\text { ED-NOS } \\
\text { BH }\end{array}$ & $M$ & 26 & \begin{tabular}{|l|}
7154 \\
926 \\
466 \\
2337 \\
2899 \\
526 \\
\end{tabular} & 97 & $\begin{array}{l}43(0.6 \%) \\
3(0.3 \%) \\
3(0.6 \%) \\
18(0.8 \%) \\
17(0.6 \%) \\
2(0.4 \%)\end{array}$ & $\begin{array}{l}\mathrm{ND} \\
\mathrm{ND} \\
\mathrm{ND} \\
\mathrm{ND} \\
\mathrm{ND} \\
\mathrm{ND}\end{array}$ & $\begin{array}{l}\mathrm{ND} \\
\mathrm{ND} \\
\mathrm{ND} \\
\mathrm{ND} \\
\mathrm{ND} \\
\mathrm{ND}\end{array}$ & $\begin{array}{l}\mathrm{ND} \\
\mathrm{ND} \\
\mathrm{ND} \\
\mathrm{ND} \\
\mathrm{ND} \\
\mathrm{ND}\end{array}$ \\
\hline $\begin{array}{l}\text { Kask et coll. } 2016 \\
\text { [70] }\end{array}$ & DSM-IV & AN & $\mathrm{H}$ & 18 & 8069 & 100 & $204(2.5 \%)$ & $\mathrm{ND}$ & ND & $\mathrm{ND}$ \\
\hline Gershon et coll. 1984 & SADS, DSM-III et RDC & $A N$ & $H$ & 25 & 24 & ND & $2(8.3 \%)$ & 0 & $1(4 \%)$ & $1(4 \%)$ \\
\hline
\end{tabular}




\begin{tabular}{|c|c|c|c|c|c|c|c|c|c|c|}
\hline [71] & & & & & & & & & & \\
\hline $\begin{array}{l}\text { Stern et coll. } 1984 \\
\text { [72] }\end{array}$ & $\begin{array}{l}\text { Semi-structured } \\
\text { interviews, RDC }\end{array}$ & $B N$ & $A$ & 24 & 27 & 100 & $5(18.5 \%)$ & $N D$ & $N D$ & $N D$ \\
\hline $\begin{array}{l}\text { Hudson et coll. } 1987 \\
\text { [73] }\end{array}$ & $D I S, D S M-I I I$ & $B N$ & $A$ & 26 & 70 & 100 & $8(11.4 \%)$ & $8(11.4 \%)$ & $N D$ & $N D$ \\
\hline $\begin{array}{l}\text { Hudson et coll. } 1988 \\
\text { [74] }\end{array}$ & DIS et SADS, DSM-III & $B N$ & $A$ & 33 & 70 & 100 & $6(8.6 \%)$ & $6(8.6 \%)$ & $N D$ & $N D$ \\
\hline $\begin{array}{l}\text { Toner, Garfinkel \& } \\
\text { Garner } 1988 \text { [75] }\end{array}$ & $D I S, D S M-I I I$ & $\begin{array}{l}\text { AN (in remission, } \\
\text { asympto or sympto) }\end{array}$ & $A$ & $?$ & 47 & 100 & $3(6.4 \%)$ & $3(6.4 \%)$ & $N D$ & $N D$ \\
\hline $\begin{array}{l}\text { Keck et coll. } 1990 \\
{[76]}\end{array}$ & $S C I D, D S M-I I I-R$ & $B N$ & $A$ & 28 & 67 & 100 & $4(6 \%)$ & $4(6 \%)$ & $N D$ & $N D$ \\
\hline $\begin{array}{l}\text { Halmi et coll. } 1991 \\
\text { [77] }\end{array}$ & $D I S, D S M-I I I-R$ & $\begin{array}{l}\text { AN after } 10 \text { yrs } \\
\text { follow-up } \\
\text { Controls }\end{array}$ & $H$ & 27 & $\begin{array}{l}62 \\
62\end{array}$ & $\begin{array}{l}100 \\
100\end{array}$ & $\begin{array}{l}10(16 \%) \\
1(1.6 \%)\end{array}$ & $\begin{array}{l}2(3.2 \%) \\
1(1.6 \%)\end{array}$ & $\begin{array}{l}2(3.2 \%) \\
0\end{array}$ & $\begin{array}{l}6(9.7 \%)^{a} \\
0\end{array}$ \\
\hline $\begin{array}{l}\text { Yanovski et coll. } \\
1993[78]\end{array}$ & $S C I D, D S M-I I I-R$ & $B H$ & $A$ & 37 & 43 & 76 & $1(2.3 \%)$ & $N D$ & $N D$ & $N D$ \\
\hline $\begin{array}{l}\text { Råstam et coll. } 1995 \\
\text { [79] }\end{array}$ & $S C I D-I I, D S M-I I I-R$ & $\begin{array}{l}\text { AN } 6.7 \text { yrs after } A N \\
\text { onset }\end{array}$ & $A$ & 21 & 51 & 94 & $2(3.9 \%)$ & $N D$ & $N D$ & $N D$ \\
\hline $\begin{array}{l}\text { Bushnell et coll. } 1994 \\
\text { [80] }\end{array}$ & $D I S, D S M-I I I$ & $B N$ & $A$ & 27 & 25 & 100 & 0 & 0 & 0 & 0 \\
\hline $\begin{array}{l}\text { Grilo et coll. } 1996 \\
\text { [81] }\end{array}$ & SADS et SCID, DSM-IV & $\begin{array}{l}E D \\
A N \\
B N \\
E D-N O S\end{array}$ & $H$ & 20 & $\begin{array}{l}31 \\
11 \\
9 \\
11\end{array}$ & 100 & $\begin{array}{l}2(6.5 \%) \\
N D \\
N D \\
N D\end{array}$ & $\begin{array}{l}N D \\
N D \\
N D \\
N D\end{array}$ & $\begin{array}{l}N D \\
N D \\
N D \\
N D\end{array}$ & $\begin{array}{l}N D \\
N D \\
N D \\
N D\end{array}$ \\
\hline $\begin{array}{l}\text { Lilenfeld et coll. } 1998 \\
\text { [82] }\end{array}$ & $S A D S, D S M-I I I-R$ & $\begin{array}{l}E D \\
A N \\
B N\end{array}$ & $A$ & 25 & $\begin{array}{l}73 \\
26 \\
47\end{array}$ & 100 & $\begin{array}{l}1(1.4 \%)^{*} \\
0 \\
1(2.1 \%)\end{array}$ & $N D$ & $N D$ & $N D$ \\
\hline $\begin{array}{l}\text { Telch \& Stice } 1998 \\
\text { [83] }\end{array}$ & $S C I D, D S M-I I I-R$ & $B H$ & $A$ & 43 & 61 & 100 & $1(1.6 \%)$ & $N D$ & $N D$ & $N D$ \\
\hline $\begin{array}{l}\text { Ivarsson et coll. } 2000 \\
{[84]}\end{array}$ & $S C I D, D S M-I I I-R$ & $A N$ & $A$ & 16 & 51 & 94 & $3(5.9 \%)$ & $3(5.9 \%)$ & 0 & 0 \\
\hline $\begin{array}{l}\text { Fontenelle et coll. } \\
2003[85]\end{array}$ & $S C I D, D S M-I V$ & $B H$ & $A$ & 34 & 33 & 97 & 0 & 0 & 0 & 0 \\
\hline $\begin{array}{l}\text { Javaras et coll. } 2008 \\
\text { [86] }\end{array}$ & $S C I D, D S M-I V$ & $B H$ & $A$ & 50 & 150 & 76 & $14(9.3 \%)^{a}$ & $N D$ & $N D$ & $N D$ \\
\hline $\begin{array}{l}\text { Aspen et coll. } 2014 \\
\text { [87] }\end{array}$ & $D S M-5$ & $\begin{array}{l}E D \\
\text { Clinical ED } \\
\text { ED-NOS }\end{array}$ & $A$ & 21 & $\begin{array}{l}107 \\
40 \\
67\end{array}$ & 100 & $\begin{array}{l}3(2.8 \%) \\
1(2.5 \%) \\
2(3 \%)\end{array}$ & $\begin{array}{l}3(2.8 \%) \\
1(2.5 \%) \\
2(3 \%)\end{array}$ & $\begin{array}{l}N D \\
N D \\
N D\end{array}$ & $\begin{array}{l}N D \\
N D \\
N D\end{array}$ \\
\hline $\begin{array}{l}\text { Godart et coll. } 2015 \\
\text { [88] }\end{array}$ & $D S M-I V-T R$ & $\begin{array}{l}E D \\
A N-R, \\
A N-P, \\
B N N P \\
B N P \\
p>0.05 \text { compared to } \\
\text { controls }\end{array}$ & $M$ & 23 & $\begin{array}{l}271 \\
111 \\
55 \\
19 \\
86\end{array}$ & 100 & $\begin{array}{l}49(18.1 \%) \\
9(8.1 \%)^{a} \\
16(29.1 \%) \\
2(10.5 \%) \\
22(25.6 \%)\end{array}$ & $\begin{array}{l}42(15.5 \%) \\
7(6.3 \%) \\
14(25.5 \%) \\
2(10.5 \%) \\
19(22.1 \%)\end{array}$ & $\begin{array}{l}7(2.6 \%) \\
2(1.8 \%) \\
2(3.6 \%) \\
0 \\
3(3.5 \%)\end{array}$ & $\begin{array}{l}0 \\
0 \\
0 \\
0 \\
0\end{array}$ \\
\hline $\begin{array}{l}\text { Tseng et coll. } 2016 \\
\text { [89] }\end{array}$ & $D S M-I V-T R, D S M-5$ & $\begin{array}{l}E D \\
A N \\
B N \\
B H \\
E D-N O S\end{array}$ & $A$ & 28 & $\begin{array}{l}288 \\
54 \\
125 \\
75 \\
34\end{array}$ & 88.2 & $\begin{array}{l}103(35.8 \%)^{a} \\
9(16.7 \%) \\
45(36 \%) \\
37(49.3 \%) \\
12(35.3 \%)\end{array}$ & $\begin{array}{l}46(16 \%) \\
6(11.1 \%) \\
18(14.4 \%) \\
17(22.7 \%) \\
5(14.7 \%)\end{array}$ & $\begin{array}{l}57(19.8 \%) \\
3(5.6 \%) \\
27(21.6 \%) \\
20(26.7 \%) \\
7(20.6 \%)\end{array}$ & $\begin{array}{l}0 \\
0 \\
0 \\
0 \\
0\end{array}$ \\
\hline $\begin{array}{l}\text { Welch et coll. } 2016 \\
\text { [90] }\end{array}$ & $D S M-I V$ & $B H$ & $M$ & 24 & 850 & 95.4 & $35(4.1 \%)^{a}$ & $N D$ & $N D$ & $N D$ \\
\hline $\begin{array}{l}\text { Marzola et coll. } 2017 \\
\text { [91] }\end{array}$ & $D S M-5$ & $\begin{array}{l}A N \\
A N-R \\
A N-P\end{array}$ & $H$ & 25 & $\begin{array}{l}98 \\
64 \\
34\end{array}$ & 100 & 0 & 0 & 0 & 0 \\
\hline
\end{tabular}

In italics: studies [71 to 91) comprising control groups

${ }^{a}: \mathrm{p}<0.0001$

*Following contact with the author, one patient for 1997 was omitted - same two patients.

**Exclusion of non-stable bipolar disorders.

ND : No data available

AN: Anorexia Nervosa; AN-R: Anorexia Nervosa, restricting type; AN-P: Anorexia Nervosa, purging type; B: Bulimia Nervosa; BN-N Bulimia Nervosa, non-purging type; BN-P: Bulimia Nervosa, purging type; BSD : Bipolar Spectrum Diagnostic Scale; DIS: Diagnostic Interview Schedule; DSM: Diagnostic and Statistical Manual of Mental Disorders; BH: Bulimic Hyperphagia ; MDQ : Mood Disorder Questionnaire; RDC: Research Diagnostic Criteria; SAD: Schedule for Affective Disorders and Schizophrenia; SCID: Structured Clinical Interview for DSM; Status: ( M : Mixed, H : Hospitalised, A: Ambulatory); ED: Eating Disorders ; BD: Bipolar Disorder; BD I: Type I bipolar disorder; BD II: type II bipolar disorder; BD-NS: non-specified bipolar disorder; MDE: Major Depressive Episode 
Table 4. Chronology of the onset of bipolar disorder

\begin{tabular}{|c|c|c|c|c|c|c|c|}
\hline Study & Subjects & Age & $\mathbf{N}$ & Pathology & $\begin{array}{l}\text { More than one } \\
\text { year before ED }\end{array}$ & $\begin{array}{c}\text { In the } \\
\text { same year }\end{array}$ & $\begin{array}{c}\text { More than one } \\
\text { year after ED }\end{array}$ \\
\hline $\begin{array}{l}\text { Ramacciotti et } \\
\text { coll. } 2005 \text { [28] }\end{array}$ & BD I & 40 & 14 & $\mathrm{BN}, \mathrm{BH}$ & $8 *(57.1 \%)$ & $4 *(28.6 \%)$ & $2 *(14.3 \%)$ \\
\hline $\begin{array}{l}\text { Godart et coll. } \\
2015[88]\end{array}$ & $\begin{array}{l}\text { ED } \\
\text { AN-R } \\
\text { AN-P } \\
\text { BN P } \\
\text { BN NP }\end{array}$ & $\begin{array}{l}21 \\
19 \\
21 \\
23 \\
25\end{array}$ & $\begin{array}{l}31 \\
4 \\
11 \\
15 \\
1\end{array}$ & $\begin{array}{l}\text { Manic or } \\
\text { hypomanic } \\
\text { episode }\end{array}$ & $\begin{array}{l}8(25.8 \%) \\
1(25 \%) \\
2(18.2 \%) \\
5(33.3 \%) \\
0\end{array}$ & $\begin{array}{l}12(38.7 \%) \\
2(50 \%) \\
4(36.4 \%) \\
5(33.3 \%) \\
1(100 \%)\end{array}$ & $\begin{array}{l}11(35.5 \%) \\
1(25 \%) \\
5(45.5 \%) \\
5(33.3 \%) \\
0\end{array}$ \\
\hline $\begin{array}{l}\text { McElroy et coll. } \\
2011[33]\end{array}$ & $\mathrm{BD}$ & 41 & $\begin{array}{l}70 \\
9 \\
16 \\
45\end{array}$ & $\begin{array}{l}\text { ED } \\
\text { AN } \\
\text { BN } \\
\text { BH }\end{array}$ & $\begin{array}{l}39(55.7 \%) \\
5(55.6 \%) \\
8(50 \%) \\
26(57.8 \%)\end{array}$ & $\begin{array}{l}7(10 \%) \\
1(11.1 \%) \\
1(6.2 \%) \\
5(1.1 \%)\end{array}$ & $\begin{array}{l}24(34.3 \%) \\
3(33.3 \%) \\
7(0.44 \%) \\
14(3.1 \%)\end{array}$ \\
\hline
\end{tabular}

*The number of years is not specified, only the relative chronology of onset.

AN: Anorexia Nervosa; AN-P: Anorexia Nervosa, purging type; AN-R: Anorexia Nervosa, restricting type; BN: Bulimia Nervosa; BN NP: Bulimia Nervosa, non-purging type; BN P: Bulimia Nervosa, purging type; BH: Bulimic Hyperphagia ; BD: Bipolar Disorder; ED: Eating Disorder 